\title{
1 Threats to seabirds: a global assessment
}

2

3

4

5

6

7

8

9

10

11

12

13

14

15

16

Authors: Maria P. Dias ${ }^{1 *}$, Rob Martin ${ }^{1}$, Elizabeth J. Pearmain ${ }^{1}$, Ian J. Burfield ${ }^{1}$, Cleo Small ${ }^{2}$, Richard A. Phillips $^{3}$, Oliver Yates ${ }^{4}$, Ben Lascelles ${ }^{1}$, Pablo Garcia Borboroglu ${ }^{5}$, John P. Croxall ${ }^{1}$

\section{Affiliations:}

1 - BirdLife International. The David Attenborough Building, Pembroke Street Cambridge CB2 3QZ UK

2 - BirdLife International Marine Programme, RSPB, The Lodge, Sandy, SG19 2DL

${ }^{3}$ - British Antarctic Survey. Natural Environment Research Council, High Cross, Madingley Road, Cambridge CB3 OET, UK

${ }^{4}$ - Centre for the Environment, Fishery and Aquaculture Science, Pakefield Road, Lowestoft, NR33, UK

${ }^{5}$ - Global Penguin Society, University of Washington and CONICET Argentina. Puerto Madryn U9120, Chubut, Argentina

* Corresponding author: Maria Dias, maria.dias@birdlife.org. BirdLife International. The David Attenborough Building, Pembroke Street Cambridge CB2 3QZ UK. Phone: +44 (0)1223 747540

\section{Acknowledgements}

We are very grateful to Bartek Arendarczyk, Sophie Bennett, Ricky Hibble, Eleanor Miller and Amy Palmer-Newton for assisting with the bibliographic review. We thank Rachael Alderman, Pep Arcos, Jonathon Barrington, Igor Debski, Peter Hodum, Gustavo Jimenez, Jeff Mangel, Ken Morgan, Paul Sagar, Peter Ryan, and other members of the ACAP PaCSWG, and the members of IUCN SSC Penguin Specialist Group (Alejandro Simeone, Andre Chiaradia, Barbara Wienecke, Charles-André Bost, Lauren Waller, Phil Trathan, Philip Seddon, Susie Ellis, Tom Schneider and Dee Boersma) for reviewing threats to selected species. We thank also Andy Symes, Rocio Moreno, Stuart Butchart, Paul Donald, Rory Crawford, Tammy Davies, Ana Carneiro and Tris Allinson for fruitful discussions and helpful comments on earlier versions of the manuscript. This work was supported by the International Climate Initiative (IKI) of the German Federal Ministry for the Environment, Nature Conservation, Building and Nuclear Safety (BMUB), by the Royal Society for the Protection of Birds (RSPB) and by the Cambridge Conservation Initiative (CCl) Collaborative Fund for Conservation. 


\title{
34 Threats to seabirds: a global assessment
}

35

36

37

\begin{abstract}
We present the first objective quantitative assessment of the threats to all 359 species of seabirds, identify the main challenges facing them, and outline priority actions for their conservation. We applied the standardised Threats Classification Scheme developed for the IUCN Red List to objectively assess threats to each species and analysed the data according to global IUCN threat status, taxonomic group, and primary foraging habitat (coastal or pelagic). The top three threats to seabirds in terms of number of species affected and average impact are: invasive alien species, affecting 165 species across all the most threatened groups; bycatch in fisheries, affecting fewer species (100) but with the greatest average impact; and climate change/severe weather, affecting 96 species. In addition to impacting $86 \%$ of globally threatened species, these three top threats also affect $81 \%$ of the species currently classified as Near Threatened or as Least Concern but declining. Reversing these three threats would benefit twothirds of all species and c. 380 million individual seabirds (c. $45 \%$ of the total global seabird population). Most seabirds (c. 70\%), especially globally threatened species, face multiple threats. For albatrosses, petrels and penguins in particular (the three most threatened groups of seabirds), it is essential to tackle both terrestrial and marine threats to reverse declines. As the negative effects of climate change are harder to mitigate, it is vital to compensate by addressing other major threats that often affect the same species, such as invasive alien species and bycatch, for which proven solutions exist.
\end{abstract}

Keywords: conservation; globally threatened species; human impacts; marine birds. 


\section{Introduction}

Seabirds are one of the most threatened groups of birds (Croxall et al., 2012; BirdLife International, 2018a). They are also regarded as good indicators of the health of marine ecosystems (Piatt and Sydeman, 2007; Parsons et al., 2008), and have a key role in marine ecosystems, with an overall consumption of biomass of the same order of magnitude as global fisheries landings (Brooke, 2004; Cury et al., 2011). They occur across all oceans, from coastal areas to the high seas, and are easier to study than most other marine animals because they are readily visible at sea and depend on land to breed, allowing for a better understanding of their population trends and of their threats.

The latest assessment of the global threat status of seabirds, using the International Union for Conservation of Nature (IUCN) Red List criteria, revealed that $31 \%$ of all seabird species are globally threatened (i.e. Critically Endangered, Endangered or Vulnerable; 110 of 359 species), and another $11 \%$ (40 species) are Near Threatened (NT) (BirdLife International, 2018b; Figure A1, Appendix 3). Additionally, almost half of all species (47\%) have declining population trends (BirdLife International, 2018b). Some of the drivers of these declines are threats faced at the colonies, such as invasive alien species (Spatz et al., 2014, 2017), whereas others operate at sea, including incidental mortality (bycatch) in fisheries, and overfishing (Žydelis et al., 2009; Anderson et al., 2011; Grémillet et al., 2018). Most previous reviews of threats to seabirds have focused on the causes of declines of specific groups, e.g. albatrosses (Phillips et al., 2016), petrels (Rodríguez et al., 2019), penguins (Borboroglu and Boersma, 2013; Trathan et al., 2015), or on the impact of a single threat, e.g. longline or gillnet bycatch (Anderson et al., 2011, Žydelis et al., 2009). The only global review to date was based on data up to 2010 and focused only on globally threatened seabirds (Croxall et al., 2012). However, to understand the conservation status of this group worldwide, it is important to assess the anthropogenic and natural pressures affecting all species, since many relatively abundant and widespread species of Least Concern on the IUCN Red List are now also in decline (e.g. Little Auk Alle alle, Fort et al., 2013; Chinstrap Penguin Pygoscelis antarcticus, Korczak-Abshire et al., 2012; Arctic Tern Sterna paradisaea, Burnham et al., 2017).

We present the results of the first quantitative review of the threats affecting all seabird species globally. We used data from more than 900 publications and a standardised assessment approach (the IUCN Red List Threats Classification Scheme; IUCN, 2012; Salafsky et al., 2008), aiming to: a) identify the main ongoing drivers of population declines of seabirds globally; b) provide the first systematic appraisal of the overall impacts of each threat on multiple species; c) quantify the number of individual seabirds exposed to each threat; and d) highlight some of the challenges and priority actions needed and to improve the conservation status of seabirds.

\section{Materials and Methods}

\subsection{Selection and categorisation of species}

We followed the taxonomy used by BirdLife International for the IUCN Red List (del Hoyo et al., 2014; BirdLife International, 2018b) and considered seabirds to be those species for which a large proportion of the population rely on the marine environment for at least part of the year (Croxall et al., 2012). This criterion was met by 359 extant species (list available at BirdLife International, 2018b and in Appendix 1). We grouped species based on taxonomy: albatrosses; large petrels and shearwaters; gadfly petrels (genera Pterodroma and Pseudobulweria); storm-petrels; other small petrels; penguins; auks; skuas; terns; gulls; frigatebirds and tropicbirds; gannets and boobies; cormorants and pelicans; sea ducks and allies; phalaropes (Appendix 1). We also split species into "pelagic" and "coastal" based on the definition provided by Croxall et al. (2012): "pelagic seabirds" are those that primarily use marine deep water (typically $>200 \mathrm{~m}$ in depth), or neritic, continental shelf water; and "coastal seabirds" are those that primarily use inshore waters (typically $<8 \mathrm{~km}$ from the shoreline; see Appendix 1 ). The global 
population trend of each species was also used in some analyses (using two categories: declining versus stable/increasing/unknown; BirdLife International, 2018b).

\subsection{Data sources and threats classification}

For the first time, threats were systematically assessed for all 359 seabird species. We undertook a detailed review of the seabird threat data, held by BirdLife International, which are used to support the global status assessment of bird species for the IUCN Red List (BirdLife International, 2018b), and the consistency of threat scoring between species was rigorously checked. We collected data through a combination of expert consultation (in collaboration with the respective seabird IUCN Species Survival Commission (SSC) Specialist Groups) and a comprehensive bibliographic search for studies reporting threats to each seabird species. In a first stage, we consulted summary species accounts published in the Handbook of the Birds of the World Alive (HBW Alive, 2018), supplemented by regional accounts from the Birds of North America (BNA online, 2018), New Zealand Birds Online (NZ Birds Online, 2018) and the Australian Government Species Profile and Threats Database (Department of the Environment and Energy, 2018). Secondly, we conducted searches in Web of Knowledge and Google Scholar, first using the *species name* (scientific name and common name separately) + "threat", and then using the *species name* and each threat named in the results of the preceding search. For species listed under the Agreement on the Conservation of Albatrosses and Petrels (ACAP), the ACAP Secretariat and relevant working groups reviewed the revised threat codings, and for penguins, the IUCN SSC Penguin Specialist Group performed this role, allowing the incorporation of additional literature and unpublished data. Overall, information from over 900 publications (each referenced to the appropriate species in the factsheets available on the BirdLife Data Zone; BirdLife International, 2018b) was used to revise the 'threats' texts that form part of the IUCN Red List factsheets and assessments (BirdLife International, 2018b).

Threats were classified using the IUCN Red List Threats Classification Scheme version 3.2 (Salafsky et al., 2008; IUCN, 2012). This scheme defines threats as "the proximate human activities or processes that have impacted, are impacting, or may impact the status of the taxon being assessed. Direct threats are synonymous with sources of stress and proximate pressures" (IUCN, 2012). In other words, and in the context of this study, a threat is a human activity or other process that affects the current conservation status of a species by causing a population or range reduction.

Each threat was coded initially using the IUCN Red List Threats Classification Scheme, down to Level 3 (the most detailed classification level) where possible (IUCN, 2012). For each threat, we assessed: 1) timing (i.e. ongoing; past but likely to return; past and unlikely to return; future); 2 ) scope (i.e. the proportion of the total population affected: minority (<50\%); majority $(50-90 \%)$; whole $(>90 \%)$ ); and 3) severity (i.e. the rate of population decline caused by the threat within its scope: very rapid; rapid; slow but significant; negligible; causing/could cause fluctuations) (IUCN, 2012 and Table 1). Each threat at the most detailed level can be recorded only once against a species, with the exception of 'Invasive \& other problematic species, genes \& diseases', for which an entry for each problematic species is possible. As one threat can have different timing and severity across the range of a species, the following convention was applied: 'Ongoing' threats were prioritised over 'Future' threats, which were prioritised over 'Past' threats. Hence, a slow, ongoing reduction was coded in preference to a rapid, past reduction. Stresses, which are the mechanism by which a threat directly or indirectly impacts the species, such as species mortality or ecosystem degradation, were also recorded as part of the IUCN threat assessment approach (IUCN, 2012). Further relevant detail beyond that required for the IUCN assessment was also noted when available, in particular the type of fishing gear and the scale of the fishery (small versus large) associated with the impact of bycatch. Overall, this process resulted in the compilation of 1,637 records of threats to 359 seabird species.

The IUCN Red List Threats Classification Scheme was developed to be applied across all species of plants, animals and fungi, and thus often lacks resolution when applied to a specific group. For example, bycatch and overfishing, two frequent threats to seabirds (Croxall et al., 2012), are allocated the same threat code under the IUCN scheme (Level 1 = Biological Resource Use, Level $2=$ Fishing \& 
harvesting aquatic resources, and Level $3=$ Unintentional effects). We therefore refined the threats classification by splitting: 1) "Biological resource use" into: "Bycatch", "Overfishing", "Disturbance", "Hunting/trapping" and "Logging \& wood harvesting"; 2) "Invasive and other problematic species, genes \& diseases" into "Invasive alien species" and "Diseases"; 3) "Agriculture \& aquaculture" into "Agriculture" and "Aquaculture"; and 4) "Light pollution" from "Pollution" (see Appendix 2 for a more detailed explanation). We assumed the same impact score of "bycatch" and "overfishing" for species affected by both $(n=34)$, as it was not possible to distinguish their relative impacts (see above). The final list of threats considered in the analyses (Table A2.1, Appendix 2) was thus a combination of the original IUCN Red List classification of Level 1 threats (IUCN, 2012), modified as indicated above (see also Table A2.2, Appendix 2).

\subsection{Data analysis}

All the analyses (except where noted otherwise) considered only threats that were coded to the timing category "ongoing", with a known and non-zero scope and severity. We also analysed the threats separately for "pelagic" and "coastal" species, and for specific groups of seabirds (see section 2.1. above). For these latter analyses, we distinguished terrestrial threats (e.g. invasive alien species, disturbance at colonies) from marine threats (e.g. overfishing, bycatch). Climate change/severe weather was considered in a separate category; see Table A2.2, Appendix 2 for more details on threats classified as marine or terrestrial). We estimated the impact of each ongoing threat on each species by multiplying the mean scope (the proportion of the population affected; see Table 1) by the mean severity (Table 1; Garnett et al., 2018), and categorised these into four levels, from "low" to "very high" (Table 1). For threats with multiple coding per species (see above), we used the highest value of impact. We also calculated the overall impact of each threat by summing the impact scores across all species.

Finally, we estimated the total number of birds $(T)$ exposed to each threat (i) by summing the product of the global abundance of each species affected by the threat, and the scope of the threat,

$$
T_{i}=\sum_{s p=1}^{n} A_{s p} * S_{i, s p}
$$

where $A=$ abundance of species $s p, \mathrm{~S}=$ scope of the threat $i$ to species $s p$. The global abundance of each species was extracted from the IUCN Red List database (BirdLife International, 2018b) by multiplying the number of mature individuals (available for $95 \%$ of the species) by 1.5 , to account for the number of non-breeders in the population (Brooke, 2004). In order to address the uncertainty associated with this estimate (given the large range of most estimates of abundance and of the values of scope - see Table 1), we applied a bootstrap approach (1,000 repetitions), by selecting random values within the intervals of abundance (i.e. between the minimum and maximum abundance) and scope (i.e. a random value between the minimum and maximum scope for each category - see Table 1) of each species, from which we derived a $95 \%$ confidence interval. These analyses were carried out separately for species classified as: 1) globally threatened; 2) Near Threatened and Least Concern with a declining trend and 3) Least Concern with a non-declining trend.

\section{Results}

\subsection{Threats to all seabird species}

Invasive alien species, bycatch, hunting/trapping, climate change/severe weather and disturbance are the ongoing threats affecting most seabird species, with each affecting more than a fifth of all species (Figure 1 and Table 2). Pollution, overfishing and problematic native species also affect many seabird species (more than 50 each; Figure 1). Bycatch, invasive alien species, overfishing and climate change/severe weather are the threats causing highest impacts on average (Figure 1 and Table 2). The impacts of hunting/trapping and disturbance are relatively low by comparison (Figure 1 and Table 2); in contrast, diseases and natural system modifications have high impacts on the few species affected (15 and 10 species, respectively; Figure 1). Invasive alien species have the highest overall impact (i.e. the 
sum of all impacts on all species affected by this threat), followed by bycatch and climate change/severe weather (Table 2).

We estimate that more than 170 million individual birds ( $>20 \%$ of all seabirds) are currently exposed to the individual impacts of bycatch, invasive alien species and climate change/severe weather (Figure 2), and that together more than 380 million (c. $45 \%$ of all seabirds) are exposed to at least one of these three threats.

Overall, 301 (84\%) of the 359 seabird species are impacted by at least one ongoing threat. About $70 \%$ of these are affected by at least two threats and $46 \%$ by at least three threats $(n=301)$. On average, each seabird species is affected by three ongoing threats $(2.85 \pm 0.12$, range $=1-11, n=301)$.

\subsection{Threats to globally threatened species}

The 110 globally threatened seabird species are largely affected by the same threats highlighted above - invasive alien species, bycatch, climate change/severe weather, hunting/trapping and overfishing (Figure 3 and Table 2; see also Figure A2 in Appendix 3). Problematic native species are also a major threat for globally threatened species, both pelagic and coastal. Disturbance is the threat affecting most coastal species, along with hunting/trapping, although mainly with medium or low impact (Figure 3).

\subsection{Threats to Near Threatened and declining Least Concern species}

Invasive alien species, climate change/severe weather, bycatch and hunting/trapping are also the threats affecting the highest number of Near Threatened (NT) and Least Concern (LC) species with a declining trend; each affects $>30 \%$ of the species in this group (Figure A3 in Appendix 3 ).

The populations of these species comprise nearly half of all individual seabirds in the world (45\%-47\%); about half of birds exposed to some of the major threats (especially bycatch, climate change/severe weather and invasive alien species) are NT and declining LC (Figure 2); $81 \%$ of the species currently NT or LC with declining trends are impacted by at least one of these three threats.

\subsection{Threats to groups of seabirds}

The major threats to particular groups of highly threatened species are indicated in Figure 4 (see also Figure A4, Appendix 3, for the percentage of threatened species per group). Albatrosses are particularly affected by bycatch ( $90 \%$ of species). In addition, around half of albatross species (13 of 22) are affected by at least one terrestrial threat, mostly invasive alien species but also diseases, which have a high impact (Table 3), and over one-third are affected by climate change/severe weather.

More than $80 \%$ of penguin species are affected by climate change/severe weather (a higher proportion than any other seabird group). Marine threats such as overfishing, bycatch and pollution also have large impacts on several species of penguins (Figure 4). The main threats at colonies are invasive alien species, problematic native species and disturbance, albeit with lower estimated impacts on average. Around half of the penguin species suffer medium, high or very high impacts from both marine and terrestrial threats (marine - pollution or overfishing; terrestrial - usually problematic native species; Table 3).

Invasive alien species and bycatch are also important threats for large petrels and shearwaters (eight species are affected by both these threats; Table 3), as is light pollution (Figure 4). Cormorants and pelicans are also impacted by a combination of several terrestrial (including invasive alien species and problematic native species) and marine threats (bycatch, overfishing and pollution; Figure 4 and Table 3). In contrast, gadfly petrels and storm-petrels are almost exclusively impacted by terrestrial threats, particularly by invasive alien species (and light pollution in the case of gadfly petrels; Figure 4).

\subsection{Invasive alien species}

Rats Rattus spp. and cats Felis catus are the invasive alien species impacting the highest number of seabird species (more than 100 and 90, respectively; Figure 5). Sixty-three seabird species (38\% of those affected by invasive alien species) are impacted by both rats and cats. Mice (Mus spp. and Peromyscus maniculatus) affect a smaller number of species (22, of which 20 are Procellariiformes - albatrosses, large petrels \& shearwaters, gadfly petrels, prions and storm-petrels), but often with high severity. 


\subsection{Bycatch}

Large-scale fisheries are causing declines of most species affected by bycatch $(>80)$, whereas $<40$ species are affected by small-scale fisheries; Figure 6). The average impacts (scope and severity) of large and small-scale fisheries are, however, similar (Figure 6). Gillnet fisheries affect more species than both average severity and scope (Figure 6).

\subsection{Climate change and severe weather}

Climate change/severe weather impacts seabirds mostly due to habitat shifting and alteration, and temperature extremes (almost 40 species are affected by each of these threats, and with relatively high scope; Figure 7). Storms/flooding impact more than 20 species of seabirds, and with lower scope (Figure 7).

Species impacted by climate change are also affected by three other threats on average (2.99 \pm 0.2 ; mean $\pm \mathrm{SE}$ ), including invasive alien species $(52 \%)$, bycatch $(43 \%)$, and c. $30 \%$ by each of overfishing, hunting/trapping and/or pollution (Figure A5, Appendix 3 ). For only $11 \%$ of seabird species is climate change/severe weather the only threat.

\section{Discussion}

This is the first comprehensive analysis to use consistent, objective criteria to assess the threats to all 359 seabird species worldwide. We found that invasive alien species, bycatch and climate change/severe weather are the top three threats to seabirds in terms of the number of species affected (165, 100 and 96, respectively; Figure 1), overall impacts (Table 2), and the estimated total number of individual birds potentially affected (Figure 2). Hunting/trapping and disturbance also affect many species ( 97 and 73 , i.e. $27 \%$ and $20 \%$, respectively), but with a low impact on average; conversely, overfishing has a relatively high impact on fewer species (54, i.e. $15 \%)$.

A comparison with the threat assessment made in 2010 is possible for globally threatened species (Croxall et al., 2012), despite minor changes in the list of species, and some differences in methods (e.g. checks for consistency in scoring threats across groups were not made in the previous study). Our results confirm the persistence of top threats such as invasive alien species and climate change/severe weather, which still affect a similar number of species (Figure 8). Threats related to fishing have increased since the previous assessment, with bycatch now impacting 50 rather than 40 , and overfishing 22 rather than 10 globally threatened species (Figure 8). This is partly due to better understanding of the impacts of gillnet fisheries on seabirds (Žydelis et al., 2009; Crawford et al., 2017), especially coastal species such as sea ducks (Žydelis et al., 2009), including some species which have recently been uplisted to globally threatened (e.g. Long-tailed Duck Clangula hyemalis, Horned Grebe Podiceps auritus). The relevance of overfishing has also increased, both in pelagic and coastal species (e.g. penguins and cormorants; e.g. Crawford et al., 2015; Trathan et al., 2015). In contrast, the threat from marine pollution has decreased, now affecting 23 rather than 30 globally threatened species. The threat from pollution is largely related to oil spills, a well-known and conspicuous threat to seabirds during the 1970s and 1980s. Oil spill events has decreased greatly in recent decades (Roser, 2018), with a consequent predictable reduction of its impact on seabirds when compared with the situation at the end of the last century (Camphuysen, 1998; Clark, 1984).

The top threats currently affecting globally threatened species largely coincide with those affecting NT and LC species with declining trends (Table 2 and Figures A2 and A3, Appendix 3), which represent one third of all species, and half the total number of individual seabirds. Therefore, tackling the current major problems faced by globally threatened species will also reduce the exposure of hundreds of millions of other (currently non-threatened) seabirds to these threats (Figure 2).

\subsection{Major threats on land}


Our study highlighted that invasive alien species, particularly rats and cats, are the major threat to seabird species globally. Therefore, eradication or control of rodents and cats is the major priority in terms of conservation of seabirds at their colonies (Phillips et al., 2016; Spatz et al., 2017; Holmes et al., 2019; Rodríguez et al., 2019) along with enhanced biosecurity measures to prevent re-invasion or new introductions (particularly for sites in proximity to human habitation) and, if necessary and where feasible, post-eradication restoration to provide habitat suitable for recruiting additional seabirds to now-safe sites (Borrelle et al., 2018). The frequent co-occurrence of rats and cats poses an additional challenge in requiring simultaneous eradication (Zavaleta et al., 2001; Rayner et al., 2007).

Hunting/trapping at colonies is the second major threat on land in terms of number of species affected, and the top threat to coastal globally threatened species. This is a well-known issue (Chen et al., 2009; Gaston and Robertson, 2010; Merkel et al., 2014, 2016; Phillips et al., 2016), and needs to be addressed in close collaboration with local communities and authorities. Hunting/trapping can also occur at sea (Bugoni et al., 2008; Alfaro-Shigueto et al., 2016; Frederiksen et al., 2016), although impacts are poorly known (Phillips et al., 2016). Disturbance is also a relevant threat in terms of number of species affected globally, and coastal globally threatened species are particularly affected (Figure 3 ). Disturbance of seabirds at their colonies can lead to reduced breeding success (Giese, 1996; Bolduc and Guillemette, 2003; Watson et al., 2014) or even to permanent abandonment of the site (Carney and Sydeman, 1999). The increase of ecotourism activities can pose an additional challenge (Palacios et al., 2018), which is nonetheless solvable by implementing the necessary regulations to control the access to important seabird colonies (Ellenberg et al., 2006).

Other relevant threats on land are light pollution (affecting mostly gadfly petrels, large petrels/shearwaters and storm-petrels (Rodríguez et al., 2017, 2019), problematic native species (especially for cormorants/pelicans, storm-petrels and penguins) and diseases (affecting mostly albatrosses and penguins). These threats also have some known and implementable solutions, such as avoidance or minimization of light sources (especially during fledging periods in high-risk areas; Gineste et al., 2017; Rodríguez et al., 2017), artificial nests for problematic native species competing for nesting burrows (Bolton et al., 2004), and vaccination against diseases in critical cases (Bourret et al., 2018).

\subsection{Major threats at sea}

We confirmed that bycatch is still a major threat to albatrosses, large petrels/shearwaters and penguins (Trathan et al., 2015; Phillips et al., 2016), and found that large-scale fisheries are driving declines in more than twice as many species as small-scale fisheries (Figure 6). Although the average impacts (scope and severity) of large and small-scale fisheries seem to be similar, impacts from small-scale fisheries are generally less well-known (Lewison et al., 2004; Chuenpagdee et al., 2006; Soykan et al., 2008). Longline and trawl fisheries involve the gear types with greatest impact in terms of both average severity and scope (especially for albatrosses and large petrels/shearwaters; Tuck et al., 2001; Barbraud et al., 2009).

Many studies have shown that bycatch in longlining and trawl fisheries can be mitigated effectively with the implementation of operational and technical measures. Depending on the characteristics of the fishery, location, season and associated at-risk seabird species, single measures can be effective, such as discard management or bird-scaring lines on trawl vessels (Bull, 2007; Pierre et al., 2012; Maree et al., 2014; Tamini et al., 2015) and hook-shielding devices in pelagic longline vessels (Sullivan et al., 2018). However, measures used in combination are most effective, such as night setting, bird-scaring lines and weighted branch lines for longline vessels (Brothers et al., 1999; ACAP, 2017a, 2017b, 2017c; Domingo et al., 2017; Paterson et al., 2017).

Many Regional Fisheries Management Organisations (RFMOs), and some national fisheries bodies in areas with high bycatch rates, have adopted regulations that seek to minimize bycatch (Anderson et al., 2011; Gilman, 2011; Phillips et al., 2016). The challenge, however, is ensuring practical implementation of the measures and compliance with the regulations, which requires industry-specific solutions and support to ensure validity of the measures and avoid cross-taxa effects (Gilman et al., 2005; Melvin et al., 2019). Gillnet fisheries are thought to affect more species (Figure 6), especially diving seabirds such as sea ducks and auks (Žydelis et al., 2009). However, and in contrast with the 
situation for the fishing gears mentioned above, solutions for gillnet bycatch remain elusive and should be regarded as research priorities (but see Mangel et al., 2018; Melvin et al., 1999).

Overfishing is also a top marine threat. It affects fewer species than other top threats, but with considerably greater impact (Figures 1, 2, Table 2). Overfishing is the main cause of decline of 24 species (e.g. Bank Cormorant Phalacrocorax neglectus and Cape Cormorant Phalacrocorax capensis; Crawford et al., 2008, 2015); and is often associated with bycatch (more than $60 \%$ of the species impacted by overfishing are also affected by bycatch). Tackling the problem of overfishing may involve the creation of Marine Protected Areas (Hyrenbach et al., 2000; Lascelles et al., 2012), including no-take zones (seasonal or permanent) in some critical cases (Daunt et al., 2008; Pichegru et al., 2010). However, it chiefly requires the effective implementation of ecosystem-based management of foragefisheries within the context of wider, multi-stakeholder Marine Spatial Planning (Ardron et al., 2008).

\subsection{Scope and scale of management approaches}

Many seabird species are impacted by both marine and terrestrial threats, and a subset of these (72 species, including 38 globally threatened species and 20 NT) have at least one marine and one terrestrial threat of medium or higher impact. For example, 27 species are impacted by both invasive alien species and bycatch (particularly albatrosses and large petrels/shearwaters, but also some auks and sea ducks; Table 3). Half of the penguin and auk species face a terrestrial and a marine threat with a medium to very high impact (usually invasive alien species or problematic native species and pollution; Table 3). The co-occurrence of medium or high impact terrestrial and marine threats emphasises the need for "ridge to reef" approaches (Rude et al., 2016; IUCN, 2018), whereby management plans aiming to protect seabird species and their habitats should necessarily include measures to address threats both on land and at sea. The appropriate measures at sea depend on the species and the relevant spatial scales of their foraging ranges: whereas short-ranging species such as cormorants and some penguin species benefit most from site-based forms of protection (e.g. wellmanaged Marine Protected Areas), wide-ranging species such as albatrosses, petrels and shearwaters will also require measures at the larger scale (even Large Marine Ecosystem; Sherman et al., 2003), particularly in relation to effective fisheries management, notably bycatch regulations (Oppel et al., 2018).

\subsection{Climate change}

Most of the top threats already mentioned (invasive alien species, bycatch, hunting/trapping, disturbance and overfishing) have known and tested solutions, at least in principle and in part. Climate change/severe weather are different in that there is limited prospect of direct mitigation of most of the main known or potential impacts. These include changes in oceanographic processes (resulting in declining in food availability around colonies), increased frequency of extreme weather events, inundation of colonies due to sea level rise or severe rainfall storms, or increased occurrence and virulence of avian pathogens (reviewed by Grémillet and Boulinier, 2009; Barbraud et al., 2012; Sydeman et al., 2012; Phillips et al., 2016). Translocations (and managed retreat) are a possibility in some cases (Deguchi et al., 2014; Miskelly et al., 2009), but challenging to execute for many species, due to the high costs and logistical difficulties.

Nevertheless, we show that most species (89\%) affected by climate change/severe weather are also affected by other threats ( $3.37 \pm 0.2$ threats on average $\pm \mathrm{SE}$ ), whose impacts are of the same order of magnitude. The most frequent threats co-occurring with climate change/severe weather are invasive alien species, bycatch, overfishing and hunting/trapping (Figure A5, Appendix 3 ). This emphasises the crucial importance of addressing effectively these other major threats in order to compensate for the negative impacts of climate change.

\subsection{Emerging threats}

The problem of marine plastics, which is global and increasing (Ryan et al., 2009; Kühn et al., 2015), and expected to affect virtually all seabird species in a few decades (Wilcox et al., 2015), is not yet identified as a cause of seabird population declines, with only one report so far of plastics causing a significant 
impact at this level (Flesh-footed Shearwater Ardenna carneipes; Lavers et al., 2014). This threat is predicted to have a higher impact on small, highly pelagic species (such as storm-petrels, prions and auklets; Wilcox et al., 2015; Roman et al., 2019), whose population sizes and demography are mostly unknown, indicating the difficulty in understanding the real impact of plastics at population levels. However, this problem is recent and so a delay would be expected before population impacts become evident for long-lived species, such as most seabirds.

The occurrence and virulence of avian pathogens is also likely to increase, especially at high latitudes, due to the enhanced spread of ectoparasites as a consequence of a warmer climate and to increasing human presence at seabird colonies (Grémillet and Boulinier, 2009; Uhart et al., 2018).

Offshore wind farming (classified here as "Energy production \& mining") is another fastgrowing issue with potential high impacts on seabirds (Furness et al., 2013), but still with limited information regarding the consequences for seabirds at the population level (Green et al., 2016). This threat is expected to affect mostly coastal species such as divers, scoters, terns and shags (Garthe and Hüppop, 2004), especially via displacement (Furness et al., 2013; Cook et al., 2018). However, highly mobile species can also be at particular risk, due to the cumulative impact resultant from multiple windfarms located across the species distributional range (Busch and Garthe, 2018)

Finally, we anticipate that in a few decades overfishing may become an even more widespread and serious problem for seabirds, including even the more pelagic species. The number of globally threatened species affected by overfishing has more than doubled since the previous assessment based on data collected up to 2010 (Croxall et al., 2012). Depletion of food resources is already regarded as the major cause of decline of 24 species (Table 2), and pressures on stocks of currently exploited coastal forage-fish species are certain to intensify, to the likely detriment of seabirds (Grémillet et al., 2018). In addition, this problem has the potential to increase with the transition of more fisheries to lower trophic levels (Pauly et al., 1998), especially those targeting mesopelagic species (St. John et al., 2016). Mesopelagic fishes, an important part of the diet of many pelagic seabirds (Watanuki and Thiebot, 2018), are the most abundant marine vertebrates (Irigoien et al., 2014) and remain largely unexploited commercially due to the currently low profitability of fishing deep-water species, especially on the highseas (St. John et al., 2016; Webb et al., 2010). This situation may soon change due to investment in new fishing technologies, along with the increasing demand for these resources from the aquaculture industry (St. John et al., 2016), with potentially serious implications for their current natural consumers (including seabirds).

\section{Conclusions}

Our analysis shows that invasive alien species, bycatch and climate change are the top three threats affecting seabirds globally. Together these threats affect two-thirds of seabird species and hundreds of millions of individuals. Hunting/trapping and disturbance affect many species, but with lower impacts, whereas overfishing affects comparatively few species, but with higher impacts. The relative importance of these top threats was largely consistent across different taxonomic groups of seabirds, and when considering only globally threatened species or only NT and declining LC species.

Multiple threats often affect the same species; consequently: a) management approaches tackling simultaneously both marine and terrestrial threats are essential to reverse the declining trend of numerous threatened seabird species; $b$ ) the negative effects of climate change can be greatly alleviated by addressing other top threats such as invasive alien species and bycatch, for which implementable proven solutions are largely available. However, even for invasive alien species and bycatch, there are substantial challenges to overcome. For invasive alien species, many of the priority eradications (Holmes et al., 2019) for islands uninhabited by humans have been completed. Therefore, the focus will increasingly shift to islands with human populations and to mainland areas, both posing substantial problems in relation to mortality of non-target species and control of invasive alien species (as opposed to rapid eradication), which likely require complex, long-term and costly initiatives, even where inherently feasible (Phillips, 2010; Oppel et al., 2011). 
Technical solutions to gillnet bycatch have proven hard to develop; in most longline and trawl fisheries compliance with recommended mitigation regulations remains limited (Phillips et al., 2016). Use of remote-recording electronic devices to monitor compliance may be essential to making progress. Seabirds are increasingly impacted by overfishing, especially coastal species. Theoretically, effective ecosystem-based management of marine resources around important seabird colonies can mitigate problems for these particular species, but also requires that effective plans and processes are in place to monitor and enforce compliance. Such potentially effective management systems remain elusive (except at very small scales) anywhere in the world, even within the Economic Exclusive Zones of most developed countries. They are conspicuously absent from the high seas, and radical reform of the RFMOs responsible for such management as does exist is long overdue.

Given the continuing deterioration in the conservation status of seabirds, and the increased number and severity of threats confronting them, there is an urgent need to identify and implement practical action to tackle threats to species and sites where feasibility and priority coincide. As seabirds are amongst the best indicators of the status of marine systems, the outlook for the global oceans is not encouraging. However, progress in addressing pollution (Roser, 2018), invasive alien species (Jones et al., 2016) and bycatch (Maree et al., 2014) shows what can be done; effective management of threats in key areas on land and at sea is now the great challenge.

\section{Acknowledgements}

We are very grateful to Bartek Arendarczyk, Sophie Bennett, Ricky Hibble, Eleanor Miller and Amy Palmer-Newton for assisting with the bibliographic review. We thank Rachael Alderman, Pep Arcos, Jonathon Barrington, Igor Debski, Peter Hodum, Gustavo Jimenez, Jeff Mangel, Ken Morgan, Paul Sagar, Peter Ryan, and other members of the ACAP PaCSWG, and the members of IUCN SSC Penguin Specialist Group (Alejandro Simeone, Andre Chiaradia, Barbara Wienecke, Charles-André Bost, Lauren Waller, Phil Trathan, Philip Seddon, Susie Ellis, Tom Schneider and Dee Boersma) for reviewing threats to selected species. We thank also Andy Symes, Rocio Moreno, Stuart Butchart, Paul Donald, Rory Crawford, Tammy Davies, Ana Carneiro and Tris Allinson for fruitful discussions and helpful comments on earlier versions of the manuscript. This work was supported by the International Climate Initiative (IKI) of the German Federal Ministry for the Environment, Nature Conservation, Building and Nuclear Safety (BMUB), by the Royal Society for the Protection of Birds (RSPB) and by the Cambridge Conservation Initiative (CCl) Collaborative Fund for Conservation.

\section{References}

ACAP, 2017a. ACAP Review and Best Practice Advice for Reducing the Impact of Demersal Longline Fisheries on Seabirds.

ACAP, 2017b. ACAP Review and Best Practice Advice for Reducing the Impact of Pelagic and Demersal Trawl Fisheries on Seabirds.

ACAP, 2017c. ACAP Review and Best Practice Advice for Reducing the Impact of Pelagic Longline Fisheries on Seabirds.

Alfaro-Shigueto, J., Mangel, J., Valenzuela, K., Arias-Schreiber, M., 2016. The intentional harvest of waved albatrosses Phoebastria irrorata by small-scale offshore fishermen from Salaverry port, Peru. Pan-American Journal of Aquatic Sciences 11, 70-77.

Anderson, O., Small, C., Croxall, J., Dunn, E., Sullivan, B., Yates, O., Black, A., 2011. Global seabird bycatch in longline fisheries. Endangered Species Research 14, 91-106. https://doi.org/10.3354/esr00347

Ardron, J., Gjerde, K., Pullen, S., Tilot, V., 2008. Marine spatial planning in the high seas. Marine Policy 32, 832-839. https://doi.org/10.1016/j.marpol.2008.03.018

Arnold, J.M., Brault, S., Croxall, J.P., 2006. Albatross Populations In Peril: A Population Trajectory For Black-Browed Albatrosses At South Georgia. Ecological Applications 16, 419-432. https://doi.org/10.1890/03-5340 
Barbraud, C., Delord, K., Marteau, C., Weimerskirch, H., 2009. Estimates of population size of whitechinned petrels and grey petrels at Kerguelen Islands and sensitivity to fisheries. Animal Conservation 12, 258-265. https://doi.org/10.1111/j.1469-1795.2009.00248.x

Barbraud, C., Rolland, V., Jenouvrier, S., Nevoux, M., Delord, K., Weimerskirch, H., 2012. Effects of climate change and fisheries bycatch on Southern Ocean seabirds: a review. Marine Ecology Progress Series 454, 285-307. https://doi.org/10.3354/meps09616

BirdLife International, 2018a. State of the world's birds: taking the pulse of the planet. BirdLife International, Cambridge, UK.

BirdLife International, 2018b. IUCN Red List for birds [WWW Document]. URL http://www.birdlife.org (accessed 10.9.18).

BNA online, 2018. Explore | Birds of North America Online [WWW Document]. URL https://birdsna.org/Species-Account/bna/home (accessed 1.8.19).

Bolduc, F., Guillemette, M., 2003. Human disturbance and nesting success of Common Eiders: interaction between visitors and gulls. Biological Conservation 110, 77-83. https://doi.org/10.1016/S0006-3207(02)00178-7

Bolton, M., Medeiros, R., Hothersall, B., Campos, A., 2004. The use of artificial breeding chambers as a conservation measure for cavity-nesting procellariiform seabirds: a case study of the Madeiran storm petrel (Oceanodroma castro). Biological Conservation 116, 73-80. https://doi.org/10.1016/S0006-3207(03)00178-2

Borrelle, S.B., Boersch-Supan, P.H., Gaskin, C.P., Towns, D.R., 2018. Influences on recovery of seabirds on islands where invasive predators have been eradicated, with a focus on Procellariiformes. Oryx 52, 346-358. https://doi.org/10.1017/\$0030605316000880

Bourret, V., Gamble, A., Tornos, J., Jaeger, A., Delord, K., Barbraud, C., Tortosa, P., Kada, S., Thiebot, J.B., Thibault, E., Gantelet, H., Weimerskirch, H., Garnier, R., Boulinier, T., 2018. Vaccination protects endangered albatross chicks against avian cholera. Conservation Letters 11, e12443. https://doi.org/10.1111/conl.12443

Brooke, M. de L., 2004. The food consumption of the world's seabirds. Proc Biol Sci 271, S246-S248.

Brothers, N., Cooper, J.., Løkkeborg, S., 1999. The incidental catch of seabirds by longline fisheries: worldwide review and technical guidelines for mitigation (FAO Fisheries Circular No. 937). FAO, Rome.

Bugoni, L., Neves, T.S., Leite, N.O., Carvalho, D., Sales, G., Furness, R.W., Stein, C.E., Peppes, F.V., Giffoni, B.B., Monteiro, D.S., 2008. Potential bycatch of seabirds and turtles in hook-and-line fisheries of the Itaipava Fleet, Brazil. Fisheries Research 90, 217-224. https://doi.org/10.1016/j.fishres.2007.10.013

Bull, L.S., 2007. Reducing seabird bycatch in longline, trawl and gillnet fisheries. Fish and Fisheries 8, 3156. https://doi.org/10.1111/j.1467-2979.2007.00234.x

Burnham, K.K., Burnham, J.L., Konkel, B.W., Johnson, J.A., 2017. Significant decline observed in Arctic Tern Sterna paradisaea population in northwest Greenland. Seabird 30, 39-50.

Busch, M., Garthe, S., 2018. Looking at the bigger picture: the importance of considering annual cycles in impact assessments illustrated in a migratory seabird species. ICES J Mar Sci 75, 690-700. https://doi.org/10.1093/icesjms/fsx170

Camphuysen, K.J., 1998. Beached bird surveys indicate decline in chronic oil pollution in the North Sea. Marine Pollution Bulletin 36, 519-526. https://doi.org/10.1016/S0025-326X(98)80018-0

Carney, K.M., Sydeman, W.J., 1999. A Review of Human Disturbance Effects on Nesting Colonial Waterbirds. Waterbirds: The International Journal of Waterbird Biology 22, 68-79. https://doi.org/10.2307/1521995

Chen, S., Chang, S., Liu, Y., Chan, S., Fan, Z., Chen, C., Yen, C., Guo, D., 2009. A small population and severe threats: status of the Critically Endangered Chinese crested tern Sterna bernsteini. Oryx 43, 209-212. https://doi.org/10.1017/S0030605308001142

Chuenpagdee, R., Liguori, L., Palomares, M.L., Pauly, D., 2006. Bottom-up, global estimates of smallscale marine fisheries catches. 
Clark, R.B., 1984. Impact of oil pollution on seabirds. Environmental Pollution Series A, Ecological and Biological 33, 1-22. https://doi.org/10.1016/0143-1471(84)90159-4

Cook, A.S.C.P., Humphreys, E.M., Bennet, F., Masden, E.A., Burton, N.H.K., 2018. Quantifying avian avoidance of offshore wind turbines: Current evidence and key knowledge gaps. Marine Environmental Research 140, 278-288. https://doi.org/10.1016/j.marenvres.2018.06.017

Crawford, R., Ellenberg, U., Frere, E., Hagen, C., Baird, K., Brewin, P., Crofts, S., Glass, J., Mattern, T., Pompert, J., Ross, K., Kemper, J., Ludynia, K., Sherley, R., Steinfurth, A., Suazo, C., Yorio, P., Tamini, L., Mangel, J., Bugoni, L., Jiménez Uzcátegui, G., Simeone, A., Luna-Jorquera, G., Gandini, P., Woehler, E., Pütz, K., Dann, P., Chiaradia, A., Small, C., 2017. Tangled and drowned: a global review of penguin bycatch in fisheries. Endangered Species Research 34, 373-396. https://doi.org/10.3354/esr00869

Crawford, R.J.M., Cockcroft, A.C., Dyer, B.M., Upfold, L., 2008. Divergent trends in bank cormorants Phalacrocorax neglectus breeding in South Africa's Western Cape consistent with a distributional shift of rock lobsters Jasus lalandii. African Journal of Marine Science 30, 161166. https://doi.org/10.2989/AJMS.2008.30.1.16.466

Crawford, R.J.M., Makhado, A.B., Whittington, P.A., Randall, R.M., Oosthuizen, W.H., Waller, L.J., 2015. A changing distribution of seabirds in South Africa - the possible impact of climate and its consequences. Front. Ecol. Evol. 3. https://doi.org/10.3389/fevo.2015.00010

Croxall, J.P., Butchart, S.H.M., Lascelles, B., Stattersfield, A.J., Sullivan, B., Symes, A., Taylor, P., 2012. Seabird conservation status, threats and priority actions: a global assessment. Bird Conservation International 22, 1-34. https://doi.org/10.1017/S0959270912000020

Cury, P.M., Boyd, I.L., Bonhommeau, S., Anker-Nilssen, T., Crawford, R.J.M., Furness, R.W., Mills, J.A., Murphy, E.J., Österblom, H., Paleczny, M., Piatt, J.F., Roux, J.-P., Shannon, L., Sydeman, W.J., 2011. Global Seabird Response to Forage Fish Depletion-One-Third for the Birds. Science 334, 1703-1706. https://doi.org/10.1126/science.1212928

Daunt, F., Wanless, S., Greenstreet, S.P.R., Jensen, H., Hamer, K.C., Harris, M.P., 2008. The impact of the sandeel fishery closure on seabird food consumption, distribution, and productivity in the northwestern North Sea. Can. J. Fish. Aquat. Sci. 65, 362-381. https://doi.org/10.1139/f07-164

Deguchi, T., Suryan, R.M., Ozaki, K., Jacobs, J.F., Sato, F., Nakamura, N., Balogh, G.R., 2014. Translocation and hand-rearing of the short-tailed albatross Phoebastria albatrus: early indicators of success for species conservation and island restoration. Oryx 48, 195-203. https://doi.org/10.1017/S0030605313000094

del Hoyo, J., Collar, N.J., Christie, D.A., Elliott, A., Fishpool, L.D.C., 2014. HBW and BirdLife International Illustrated Checklist of the Birds of the World. Volume 1: Non-passerines, Lynx Edicions and BirdLife International. ed. Barcelona, Spain and Cambridge, UK, Barcelona, Spain and Cambridge, UK.

Department of the Environment and Energy, 2018. Species Profiles (SPRAT) [WWW Document]. URL http://www.environment.gov.au/cgi-bin/sprat/public/sprat.pl (accessed 1.8.19).

Domingo, A., Jiménez, S., Abreu, M., Forselledo, R., Yates, O., 2017. Effectiveness of tori line use to reduce seabird bycatch in pelagic longline fishing. PLOS ONE 12, e0184465. https://doi.org/10.1371/journal.pone.0184465

Ellenberg, U., Mattern, T., Seddon, P.J., Jorquera, G.L., 2006. Physiological and reproductive consequences of human disturbance in Humboldt penguins: The need for species-specific visitor management. Biological Conservation 133, 95-106. https://doi.org/10.1016/j.biocon.2006.05.019

Fort, J., Moe, B., Strøm, H., Grémillet, D., Welcker, J., Schultner, J., Jerstad, K., Johansen, K.L., Phillips, R.A., Mosbech, A., 2013. Multicolony tracking reveals potential threats to little auks wintering in the North Atlantic from marine pollution and shrinking sea ice cover. Diversity and Distributions 19, 1322-1332. https://doi.org/10.1111/ddi.12105

Frederiksen, M., Descamps, S., Erikstad, K.E., Gaston, A.J., Gilchrist, H.G., Grémillet, D., Johansen, K.L., Kolbeinsson, Y., Linnebjerg, J.F., Mallory, M.L., McFarlane Tranquilla, L.A., Merkel, F.R., Montevecchi, W.A., Mosbech, A., Reiertsen, T.K., Robertson, G.J., Steen, H., Strøm, H., 
Thórarinsson, T.L., 2016. Migration and wintering of a declining seabird, the thick-billed murre Uria lomvia, on an ocean basin scale: Conservation implications. Biological Conservation 200, 26-35. https://doi.org/10.1016/j.biocon.2016.05.011

Furness, R.W., Wade, H.M., Masden, E.A., 2013. Assessing vulnerability of marine bird populations to offshore wind farms. Journal of Environmental Management 119, 56-66. https://doi.org/10.1016/j.jenvman.2013.01.025

Garnett, S.T., Butchart, S.H.M., Baker, G.B., Bayraktarov, E., Buchanan, K.L., Burbidge, A.A., Chauvenet, A.L.M., Christidis, L., Ehmke, G., Grace, M., Hoccom, D.G., Legge, S.M., Leiper, I., Lindenmayer, D.B., Loyn, R.H., Maron, M., McDonald, P., Menkhorst, P., Possingham, H.P., Radford, J., Reside, A.E., Watson, D.M., Watson, J.E.M., Wintle, B., Woinarski, J.C.Z., Geyle, H.M., 2018. Metrics of progress in the understanding and management of threats to Australian birds. Conservation Biology 0. https://doi.org/10.1111/cobi.13220

Garthe, S., Hüppop, O., 2004. Scaling possible adverse effects of marine wind farms on seabirds: developing and applying a vulnerability index. Journal of Applied Ecology 41, 724-734. https://doi.org/10.1111/j.0021-8901.2004.00918.x

Gaston, A.J., Robertson, G.J., 2010. Trends in the harvest of Brünnich's guillemots Uria lomvia in Newfoundland: effects of regulatory changes and winter sea ice conditions. Wildlife Biology 16, 47-55. https://doi.org/10.2981/09-020

Giese, M., 1996. Effects of human activity on adelie penguin Pygoscelis adeliae breeding success. Biological Conservation 75, 157-164. https://doi.org/10.1016/0006-3207(95)00060-7

Gilman, E., Brothers, N., Kobayashi, D.R., 2005. Principles and approaches to abate seabird by-catch in longline fisheries. Fish and Fisheries 6, 35-49. https://doi.org/10.1111/j.14672679.2005.00175.x

Gilman, E.L., 2011. Bycatch governance and best practice mitigation technology in global tuna fisheries. Marine Policy 35, 590-609. https://doi.org/10.1016/j.marpol.2011.01.021

Gineste, B., Souquet, M., Couzi, F.-X., Giloux, Y., Philippe, J.-S., Hoarau, C., Tourmetz, J., Potin, G., Le Corre, M., 2017. Tropical Shearwater population stability at Reunion Island, despite light pollution. J Ornithol 158, 385-394. https://doi.org/10.1007/s10336-016-1396-5

Green, R.E., Langston, R.H.W., McCluskie, A., Sutherland, R., Wilson, J.D., 2016. Lack of sound science in assessing wind farm impacts on seabirds. Journal of Applied Ecology 53, 1635-1641. https://doi.org/10.1111/1365-2664.12731

Grémillet, D., Boulinier, T., 2009. Spatial ecology and conservation of seabirds facing global climate change: a review. Marine Ecology Progress Series 391, 121-137. https://doi.org/10.3354/meps08212

Grémillet, D., Ponchon, A., Paleczny, M., Palomares, M.-L.D., Karpouzi, V., Pauly, D., 2018. Persisting Worldwide Seabird-Fishery Competition Despite Seabird Community Decline. Current Biology 28, 4009-4013.e2. https://doi.org/10.1016/j.cub.2018.10.051

HBW Alive, 2018. Handbook of the Birds of the World Alive | HBW Alive [WWW Document]. URL https://www.hbw.com/ (accessed 1.8.19).

Holmes, N.D., Spatz, D.R., Oppel, S., Tershy, B., Croll, D.A., Keitt, B., Genovesi, P., Burfield, I.J., Will, D.J., Bond, A.L., Wegmann, A., Aguirre-Muñoz, A., Raine, A.F., Knapp, C.R., Hung, C.-H., Wingate, D., Hagen, E., Méndez-Sánchez, F., Rocamora, G., Yuan, H.-W., Fric, J., Millett, J., Russell, J., LiskeClark, J., Vidal, E., Jourdan, H., Campbell, K., Springer, K., Swinnerton, K., Gibbons-Decherong, L., Langrand, O., Brooke, M. de L., McMinn, M., Bunbury, N., Oliveira, N., Sposimo, P., Geraldes, P., McClelland, P., Hodum, P., Ryan, P.G., Borroto-Páez, R., Pierce, R., Griffiths, R., Fisher, R.N., Wanless, R., Pasachnik, S.A., Cranwell, S., Micol, T., Butchart, S.H.M., 2019. Globally important islands where eradicating invasive mammals will benefit highly threatened vertebrates. PLOS ONE 14, e0212128. https://doi.org/10.1371/journal.pone.0212128

Hyrenbach, K.D., Forney, K.A., Dayton, P.K., 2000. Marine protected areas and ocean basin management. Aquatic Conservation: Marine and Freshwater Ecosystems 10, 437-458. https://doi.org/10.1002/1099-0755(200011/12)10:6<437::AID-AQC425>3.0.CO;2-Q 
Irigoien, X., Klevjer, T.A., Røstad, A., Martinez, U., Boyra, G., Acuña, J.L., Bode, A., Echevarria, F., Gonzalez-Gordillo, J.I., Hernandez-Leon, S., Agusti, S., Aksnes, D.L., Duarte, C.M., Kaartvedt, S., 2014. Large mesopelagic fishes biomass and trophic efficiency in the open ocean. Nature Communications 5. https://doi.org/10.1038/ncomms4271

IUCN, 2018. Ridge to Reef [WWW Document]. URL https://www.iucn.org/theme/water/ourwork/current-projects/ridge-reef (accessed 9.9.18).

IUCN, 2012. Threats Classification Scheme (Version 3.2) [WWW Document]. URL http://www.iucnredlist.org/technical-documents/classification-schemes/threats-classificationscheme. (accessed 10.9.18).

Jones, H.P., Holmes, N.D., Butchart, S.H.M., Tershy, B.R., Kappes, P.J., Corkery, I., Aguirre-Muñoz, A., Armstrong, D.P., Bonnaud, E., Burbidge, A.A., Campbell, K., Courchamp, F., Cowan, P.E., Cuthbert, R.J., Ebbert, S., Genovesi, P., Howald, G.R., Keitt, B.S., Kress, S.W., Miskelly, C.M., Oppel, S., Poncet, S., Rauzon, M.J., Rocamora, G., Russell, J.C., Samaniego-Herrera, A., Seddon, P.J., Spatz, D.R., Towns, D.R., Croll, D.A., 2016. Invasive mammal eradication on islands results in substantial conservation gains. Proc Natl Acad Sci U S A 113, 4033-4038. https://doi.org/10.1073/pnas.1521179113

Korczak-Abshire, M., Chwedorzewska, K.J., Wąsowicz, P., Bednarek, P.T., 2012. Genetic structure of declining chinstrap penguin (Pygoscelis antarcticus) populations from South Shetland Islands (Antarctica). Polar Biol 35, 1681-1689. https://doi.org/10.1007/s00300-012-1210-7

Kühn, S., Bravo Rebolledo, E.L., van Franeker, J.A., 2015. Deleterious Effects of Litter on Marine Life, in: Bergmann, M., Gutow, L., Klages, M. (Eds.), Marine Anthropogenic Litter. Springer International Publishing, Cham, pp. 75-116.

Lascelles, B.G., Langham, G.M., Ronconi, R.A., Reid, J.B., 2012. From hotspots to site protection: Identifying Marine Protected Areas for seabirds around the globe. Biological Conservation, Seabirds and Marine Protected Areas planning 156, 5-14. https://doi.org/10.1016/j.biocon.2011.12.008

Lavers, J.L., Bond, A.L., Hutton, I., 2014. Plastic ingestion by Flesh-footed Shearwaters (Puffinus carneipes): Implications for fledgling body condition and the accumulation of plastic-derived chemicals. Environmental Pollution 187, 124-129. https://doi.org/10.1016/j.envpol.2013.12.020

Lewison, R.L., Crowder, L.B., Read, A.J., Freeman, S.A., 2004. Understanding impacts of fisheries bycatch on marine megafauna. Trends in Ecology \& Evolution 19, 598-604. https://doi.org/10.1016/j.tree.2004.09.004

Mangel, J.C., Wang, J., Alfaro-Shigueto, J., Pingo, S., Jimenez, A., Carvalho, F., Swimmer, Y., Godley, B.J., 2018. Illuminating gillnets to save seabirds and the potential for multi-taxa bycatch mitigation. Royal Society Open Science 5, 180254. https://doi.org/10.1098/rsos.180254

Maree, B.A., Wanless, R.M., Fairweather, T.P., Sullivan, B.J., Yates, O., 2014. Significant reductions in mortality of threatened seabirds in a South African trawl fishery: Reduced seabird mortality in trawl fishing. Animal Conservation 17, 520-529. https://doi.org/10.1111/acv.12126

Melvin, E.F., Dietrich, K.S., Suryan, R.M., Fitzgerald, S.M., 2019. Lessons from seabird conservation in Alaskan longline fisheries. Conservation Biology 0. https://doi.org/10.1111/cobi.13288

Melvin, E.F., Parrish, J.K., Conquest, L.L., 1999. Novel Tools to Reduce Seabird Bycatch in Coastal Gillnet Fisheries. Conservation Biology 13, 1386-1397. https://doi.org/10.1046/j.15231739.1999.98426.x

Merkel, F., Boertmann, D., Falk, K., Frederiksen, M., Johansen, K., Labansen, A.L., Linnebjerg, J.F., Mosbech, A., Sonne, C., 2016. Why is the last Thick-billed Murre Uria lomvia colony in central West Greenland heading for extinction? Bird Conservation International 26, 177-191. https://doi.org/10.1017/S0959270915000040

Merkel, F., Labansen, A.L., Boertmann, D., Mosbech, A., Egevang, C., Falk, K., Linnebjerg, J.F., Frederiksen, M., Kampp, K., 2014. Declining trends in the majority of Greenland's thick-billed murre (Uria lomvia) colonies 1981-2011. Polar Biol 37, 1061-1071. https://doi.org/10.1007/s00300-014-1500-3 
Miskelly, C.M., Taylor, G.A., Gummer, H., Williams, R., 2009. Translocations of eight species of burrownesting seabirds (genera Pterodroma, Pelecanoides, Pachyptila and Puffinus: Family Procellariidae). Biological Conservation 142, 1965-1980. https://doi.org/10.1016/j.biocon.2009.03.027

NZ Birds Online, 2018. Home page | New Zealand Birds Online [WWW Document]. URL http://nzbirdsonline.org.nz/ (accessed 1.8.19).

Oppel, S., Beaven, B.M., Bolton, M., Vickery, J., Bodey, T.W., 2011. Eradication of Invasive Mammals on Islands Inhabited by Humans and Domestic Animals: Mammal Eradications on Inhabited Islands. Conservation Biology 25, 232-240. https://doi.org/10.1111/j.1523-1739.2010.01601.x

Oppel, S., Bolton, M., Carneiro, A.P.B., Dias, M.P., Green, J.A., Masello, J.F., Phillips, R.A., Owen, E., Quillfeldt, P., Beard, A., Bertrand, S., Blackburn, J., Boersma, P.D., Borges, A., Broderick, A.C., Catry, P., Cleasby, I., Clingham, E., Creuwels, J., Crofts, S., Cuthbert, R.J., Dallmeijer, H., Davies, D., Davies, R., Dilley, B.J., Dinis, H.A., Dossa, J., Dunn, M.J., Efe, M.A., Fayet, A.L., Figueiredo, L., Frederico, A.P., Gjerdrum, C., Godley, B.J., Granadeiro, J.P., Guilford, T., Hamer, K.C., Hazin, C., Hedd, A., Henry, L., Hernández-Montero, M., Hinke, J., Kokubun, N., Leat, E., Tranquilla, L.M., Metzger, B., Militão, T., Montrond, G., Mullié, W., Padget, O., Pearmain, E.J., Pollet, I.L., Pütz, K., Quintana, F., Ratcliffe, N., Ronconi, R.A., Ryan, P.G., Saldanha, S., Shoji, A., Sim, J., Small, C., Soanes, L., Takahashi, A., Trathan, P., Trivelpiece, W., Veen, J., Wakefield, E., Weber, N., Weber, S., Zango, L., Daunt, F., Ito, M., Harris, M.P., Newell, M.A., Wanless, S., González-Solís, J., Croxall, J., 2018. Spatial scales of marine conservation management for breeding seabirds. Marine Policy 98, 37-46. https://doi.org/10.1016/j.marpol.2018.08.024

Palacios, M.G., D'Amico, V.L., Bertellotti, M., 2018. Ecotourism effects on health and immunity of Magellanic penguins at two reproductive colonies with disparate touristic regimes and population trends. Conserv Physiol 6. https://doi.org/10.1093/conphys/coy060

Parsons, M., Mitchell, I., Butler, A., Ratcliffe, N., Frederiksen, M., Foster, S., Reid, J.B., 2008. Seabirds as indicators of the marine environment. ICES J Mar Sci 65, 1520-1526. https://doi.org/10.1093/icesjms/fsn155

Paterson, J.R.B., Yates, O., Holtzhausen, H., Reid, T., Shimooshili, K., Yates, S., Sullivan, B.J., Wanless, R.M., 2017. Seabird mortality in the Namibian demersal longline fishery and recommendations for best practice mitigation measures. Oryx 1-10. https://doi.org/10.1017/\$0030605317000230

Pauly, D., Christensen, V., Dalsgaard, J., Froese, R., Torres, F., 1998. Fishing Down Marine Food Webs. Science 279, 860-863. https://doi.org/10.1126/science.279.5352.860

Phillips, R.A., 2010. Eradications of invasive mammals from islands: why, where, how and what next? Emu, in: http://dx.doi.org/10.1071/MUv110n4_ED SARAÇA. pp. 1-7.

Phillips, R.A., Gales, R., Baker, G.B., Double, M.C., Favero, M., Quintana, F., Tasker, M.L., Weimerskirch, H., Uhart, M., Wolfaardt, A., 2016. The conservation status and priorities for albatrosses and large petrels. Biological Conservation 201, 169-183. https://doi.org/10.1016/j.biocon.2016.06.017

Piatt, I., Sydeman, W., 2007. Seabirds as indicators of marine ecosystems. Marine Ecology Progress Series 352, 199-204. https://doi.org/10.3354/meps07070

Pichegru, L., Grémillet, D., Crawfor, R.J.M., Ryan, P.G., 2010. Marine no-take zone rapidly benefits endangered penguin. Biology Letters 6, 498-501. https://doi.org/10.1098/rsbl.2009.0913

Pierre, J.P., Abraham, E.R., Richard, Y., Cleal, J., Middleton, D.A.J., 2012. Controlling trawler waste discharge to reduce seabird mortality. Fisheries Research 131-133, 30-38. https://doi.org/10.1016/j.fishres.2012.07.005

Rayner, M.J., Hauber, M.E., Imber, M.J., Stamp, R.K., Clout, M.N., 2007. Spatial heterogeneity of mesopredator release within an oceanic island system. PNAS 104, 20862-20865. https://doi.org/10.1073/pnas.0707414105

Rodríguez, A., Arcos, J.M., Bretagnolle, V., Dias, M.P., Holmes, N.D., Louzao, M., Provencher, J., Raine, A.F., Ramírez, F., Rodríguez, B., Ronconi, R.A., Taylor, R.S., Bonnaud, E., Borrelle, S.B., Cortés, V., Descamps, S., Friesen, V.L., Genovart, M., Hedd, A., Hodum, P., Humphries, G.R.W., Le Corre, M., Lebarbenchon, C., Martin, R., Melvin, E.F., Montevecchi, W.A., Pinet, P., Pollet, I.L., Ramos, 
R., Russell, J.C., Ryan, P.G., Sanz-Aguilar, A., Spatz, D.R., Travers, M., Votier, S.C., Wanless, R.M., Woehler, E., Chiaradia, A., 2019. Future Directions in Conservation Research on Petrels and Shearwaters. Front. Mar. Sci. 6. https://doi.org/10.3389/fmars.2019.00094

Rodríguez, A., Holmes, N.D., Ryan, P.G., Wilson, K.-J., Faulquier, L., Murillo, Y., Raine, A.F., Penniman, J.F., Neves, V., Rodríguez, B., Negro, J.J., Chiaradia, A., Dann, P., Anderson, T., Metzger, B., Shirai, M., Deppe, L., Wheeler, J., Hodum, P., Gouveia, C., Carmo, V., Carreira, G.P., DelgadoAlburqueque, L., Guerra-Correa, C., Couzi, F.-X., Travers, M., Corre, M.L., 2017. Seabird mortality induced by land-based artificial lights. Conservation Biology 31, 986-1001. https://doi.org/10.1111/cobi.12900

Roman, L., Bell, E., Wilcox, C., Hardesty, B.D., Hindell, M., 2019. Ecological drivers of marine debris ingestion in Procellariiform Seabirds. Scientific Reports 9, 916. https://doi.org/10.1038/s41598018-37324-w

Roser, M., 2018. Our World in Data - Oil Spills [WWW Document]. URL https://ourworldindata.org/oilspills (accessed 9.9.18).

Rude, J., Minks, A., Doheny, B., Tyner, M., Maher, K., Huffard, C., Hidayat, N.I., Grantham, H., 2016. Ridge to reef modelling for use within land-sea planning under data-limited conditions. Aquatic Conservation: Marine and Freshwater Ecosystems 26, 251-264. https://doi.org/10.1002/aqc. 2548

Ryan, P.G., Moore, C.J., van Franeker, J.A., Moloney, C.L., 2009. Monitoring the abundance of plastic debris in the marine environment. Philos Trans R Soc Lond B Biol Sci 364, 1999-2012. https://doi.org/10.1098/rstb.2008.0207

Salafsky, N., Salzer, D., Stattersfield, A.J., Hilton-Taylor, C., Neugarten, R., Butchart, S.H.M., Collen, B., Cox, N., Master, L.L., O'connor, S., Wilkie, D., 2008. A Standard Lexicon for Biodiversity Conservation: Unified Classifications of Threats and Actions. Conservation Biology 22, 897-911. https://doi.org/10.1111/j.1523-1739.2008.00937.x

Sherman, K., Ajayi, T., Anang, E., Cury, P., Freon, M.P., Hardman-Mountford, N.J., Ibe, C.A., Koranteng, K.A., McGlade, J., Nauen, C.C., 2003. Suitability of the large marine ecosystem concept. Fisheries research 64, 197-204.

Soykan, C.U., Moore, J.E., Zydelis, R., Crowder, L.B., Safina, C., Lewison, R.L., 2008. Why study bycatch? An introduction to the Theme Section on fisheries bycatch. Endangered Species Research 5, 91102. https://doi.org/10.3354/esr00175

Spatz, D.R., Holmes, N.D., Reguero, B.G., Butchart, S.H.M., Tershy, B.R., Croll, D.A., 2017. Managing Invasive Mammals to Conserve Globally Threatened Seabirds in a Changing Climate: Threatened seabird conservation on islands. Conservation Letters 10, 736-747. https://doi.org/10.1111/conl.12373

Spatz, D.R., Newton, K.M., Heinz, R., Tershy, B., Holmes, N.D., Butchart, S.H.M., Croll, D.A., 2014. The Biogeography of Globally Threatened Seabirds and Island Conservation Opportunities: Seabird Conservation Opportunities. Conservation Biology 28, 1282-1290. https://doi.org/10.1111/cobi.12279

St. John, M.A., Borja, A., Chust, G., Heath, M., Grigorov, I., Mariani, P., Martin, A.P., Santos, R.S., 2016. A Dark Hole in Our Understanding of Marine Ecosystems and Their Services: Perspectives from the Mesopelagic Community. Front. Mar. Sci. 3. https://doi.org/10.3389/fmars.2016.00031

Sullivan, B.J., Kibel, B., Kibel, P., Yates, O., Potts, J.M., Ingham, B., Domingo, A., Gianuca, D., Jiménez, S., Lebepe, B., Maree, B.A., Neves, T., Peppes, F., Rasehlomi, T., Silva-Costa, A., Wanless, R.M., 2018. At-sea trialling of the Hookpod: a "one-stop" mitigation solution for seabird bycatch in pelagic longline fisheries. Animal Conservation 21, 159-167. https://doi.org/10.1111/acv.12388

Sydeman, W., Thompson, S., Kitaysky, A., 2012. Seabirds and climate change: roadmap for the future. Marine Ecology Progress Series 454, 107-117. https://doi.org/10.3354/meps09806

Tamini, L.L., Chavez, L.N., Góngora, M.E., Yates, O., Rabuffetti, F.L., Sullivan, B., 2015. Estimating mortality of black-browed albatross (Thalassarche melanophris, Temminck, 1828) and other seabirds in the Argentinean factory trawl fleet and the use of bird-scaring lines as a mitigation measure. Polar Biol 38, 1867-1879. https://doi.org/10.1007/s00300-015-1747-3 
Trathan, P.N., Borboroglu, P.G., Boersma, D., Bost, C.-A., Crawford, R.J.M., Crossin, G.T., Cuthbert, R.J., Dann, P., Davis, L.S., De La Puente, S., Ellenberg, U., Lynch, H.J., Mattern, T., Pütz, K., Seddon, P.J., Trivelpiece, W., Wienecke, B., 2015. Pollution, habitat loss, fishing, and climate change as critical threats to penguins: Primary Threats to Penguins. Conservation Biology 29, 31-41. https://doi.org/10.1111/cobi.12349

Tuck, G.N., Polacheck, T., Croxall, J.P., Weimerskirch, H., 2001. Modelling the impact of fishery bycatches on albatross populations. Journal of Applied Ecology 38, 1182-1196. https://doi.org/10.1046/j.0021-8901.2001.00661.x

Uhart, M.M., Gallo, L., Quintana, F., 2018. Review of diseases (pathogen isolation, direct recovery and antibodies) in albatrosses and large petrels worldwide. Bird Conservation International 28, 169196. https://doi.org/10.1017/S0959270916000629

Watanuki, Y., Thiebot, J.-B., 2018. Factors affecting the importance of myctophids in the diet of the world's seabirds. Mar Biol 165, 79. https://doi.org/10.1007/s00227-018-3334-y

Watson, H., Bolton, M., Monaghan, P., 2014. Out of sight but not out of harm's way: Human disturbance reduces reproductive success of a cavity-nesting seabird. Biol Conserv 174, 127133. https://doi.org/10.1016/j.biocon.2014.03.020

Webb, T.J., Berghe, E.V., O'Dor, R., 2010. Biodiversity's Big Wet Secret: The Global Distribution of Marine Biological Records Reveals Chronic Under-Exploration of the Deep Pelagic Ocean. PLOS ONE 5, e10223. https://doi.org/10.1371/journal.pone.0010223

Wilcox, C., Van Sebille, E., Hardesty, B.D., 2015. Threat of plastic pollution to seabirds is global, pervasive, and increasing. Proceedings of the National Academy of Sciences 112, 11899-11904. https://doi.org/10.1073/pnas.1502108112

Zavaleta, E.S., Hobbs, R.J., Mooney, H.A., 2001. Viewing invasive species removal in a whole-ecosystem context. Trends in Ecology \& Evolution 16, 454-459. https://doi.org/10.1016/S01695347(01)02194-2

Žydelis, R., Bellebaum, J., Österblom, H., Vetemaa, M., Schirmeister, B., Stipniece, A., Dagys, M., van Eerden, M., Garthe, S., 2009. Bycatch in gillnet fisheries - An overlooked threat to waterbird populations. Biological Conservation 142, 1269-1281. https://doi.org/10.1016/j.biocon.2009.02.025 
Table 1: System for scoring impact of threats (from Garnett et al., 2018). Values within parentheses represent the percentage of the total population affected (scope) and the known or likely rate of population decline caused by the threat over three generations (severity). Impact values are the

860 average of the product of the extremes of scope and severity in each interval (mean[min(scope)* $\min ($ severity)/100, $\max ($ scope $) * \max ($ severity)/100])

\begin{tabular}{lcccc}
\hline Scope/Severity & $\begin{array}{c}\text { Very Rapid } \\
\text { Declines } \\
(>30 \%)\end{array}$ & $\begin{array}{c}\text { Rapid } \\
\text { Declines } \\
{[20-30 \%]}\end{array}$ & $\begin{array}{c}\text { Slow but Significant } \\
\text { Declines or Causing/Could } \\
\text { cause fluctuations [5-20\%[ }\end{array}$ & $\begin{array}{c}\text { Negligible } \\
\text { Declines (<5\%) }\end{array}$ \\
\hline \multirow{2}{*}{ Whole (>90\%) } & 63 & 23.5 & 11.8 & 2.9 \\
& Very high & High & Medium & Low \\
Majority [50-90\%] & 51.6 & 17.9 & 9.7 & 2.4 \\
& Very high & High & Medium & Low \\
Minority $(<50 \%)$ & 24.9 & 7.4 & 4.8 & 1.2 \\
\hline
\end{tabular}


864

\begin{tabular}{|c|c|c|c|c|c|c|c|c|c|c|}
\hline \multirow[b]{2}{*}{ Threats } & \multicolumn{4}{|c|}{ All species $(n=359)$} & \multicolumn{3}{|c|}{$\begin{array}{l}\text { Globally threatened species } \\
\qquad(\mathrm{n}=110)\end{array}$} & \multicolumn{3}{|c|}{ NT and LC species (declining) $(n=119)$} \\
\hline & $\begin{array}{c}\mathbf{N} \\
\text { species }\end{array}$ & $\begin{array}{c}\mathrm{N} \text { species } \\
\text { main threat }^{1}\end{array}$ & $\begin{array}{c}\text { Mean } \\
\text { impact }\end{array}$ & $\begin{array}{l}\text { Overall } \\
\text { impact }\end{array}$ & $\begin{array}{c}\mathbf{N} \\
\text { species }\end{array}$ & $\begin{array}{c}\text { Mean } \\
\text { impact }\end{array}$ & $\begin{array}{l}\text { Overall } \\
\text { impact }\end{array}$ & $\begin{array}{c}\mathbf{N} \\
\text { species }\end{array}$ & $\begin{array}{l}\text { Mean } \\
\text { impact }\end{array}$ & $\begin{array}{l}\text { Overall } \\
\text { impact }\end{array}$ \\
\hline Invasive alien species & 165 & 107 & $8.6 \pm 0.8$ & 1419.29 & 73 & $12.14 \pm 1.64$ & 885.89 & 62 & $6.12 \pm 0.61$ & 379.36 \\
\hline Bycatch & 100 & 70 & $9.05 \pm 0.97$ & 904.66 & 50 & $11.78 \pm 1.77$ & 589.00 & 36 & $6.68 \pm 0.75$ & 240.62 \\
\hline Climate change/severe weather & 96 & 63 & $8.07 \pm 0.47$ & 774.92 & 37 & $9.88 \pm 0.80$ & 365.53 & 43 & $7.44 \pm 0.67$ & 319.89 \\
\hline Overfishing & 54 & $24^{2}$ & $8.49 \pm 1.25$ & 458.25 & 22 & $11.89 \pm 2.81$ & 261.49 & 19 & $6.79 \pm 0.83$ & 129.09 \\
\hline Hunting/trapping & 97 & 38 & $4.05 \pm 0.6$ & 392.71 & 27 & $6.05 \pm 1.98$ & 163.37 & 35 & $4.03 \pm 0.50$ & 141.18 \\
\hline Disturbance & 73 & 25 & $3.40 \pm 0.36$ & 248.31 & 26 & $4.23 \pm 0.63$ & 110.09 & 28 & $3.37 \pm 0.57$ & 94.36 \\
\hline
\end{tabular}

Table 2: Summary of the top threats (impacting more than $20 \%$ of the species or having an high overall impact) affecting: all seabird species; only globally threatened species; only Near Threatened (NT) species and Least Concern (LC) species with declining trends. N species: number of species affected; $N$ species main threat: number of species for which the threat is the main cause of decline (i.e. highest impact); Mean impact ( \pm SE): mean impact on the species affected by the threat; Overall impact: sum of the impact scores across all species. Threats are listed in descending order of the overall impact on all species.

Disturbance

25

$3.40 \pm 0.36$

248.31

$4.23 \pm 0.63$

110.09

$3.37 \pm 0.57$

94.36 
Table 3: Seabird groups affected by both terrestrial and marine threats (excluding the ones related

871 to the climate change; see methods) with medium, high or very high impact*, and most frequent

872 interactions (only shown are those affecting $>2$ species).

\begin{tabular}{lccc}
\hline Group & $\begin{array}{c}\text { N species with } \\
\text { terrestrial and } \\
\text { marine threats }\end{array}$ & $\begin{array}{c}\text { Most frequent interactions terrestrial - } \\
\text { marine }\end{array}$ & $\begin{array}{c}\text { Number of } \\
\text { species } \\
\text { affected }\end{array}$ \\
\hline Albatrosses & $13(59 \%)$ & $\begin{array}{c}\text { Invasive alien species - Bycatch } \\
\text { Diseases - Bycatch }\end{array}$ & $\begin{array}{c}10 \\
\text { Penguins }\end{array}$ \\
& $9(50 \%)$ & $\begin{array}{c}\text { Problematic native species - Pollution } \\
\text { Invasive alien species - Pollution }\end{array}$ & 4 \\
& & $\begin{array}{c}\text { Problematic native species - Overfishing } \\
\text { Hunting/trapping - Pollution }\end{array}$ & 3 \\
& & Invasive alien species - Pollution & 3 \\
\hline Auks & $11(46 \%)$ & Invasive alien species - Bycatch & 6 \\
& & Disturbance - Pollution & 3 \\
\hline Large petrels and & $13(34 \%)$ & Invasive alien species - Bycatch & 3 \\
shearwaters & & Invasive alien species - Overfishing & 8 \\
\hline Sea ducks and allies & $10(33 \%)$ & Hunting/trapping - Pollution & 3 \\
& & Hunting/trapping - Bycatch & 7 \\
& & Invasive alien species - Bycatch & 4 \\
\hline $\begin{array}{l}\text { Cormorants and } \\
\text { pelicans }\end{array}$ & $6(18 \%)$ & Problematic native species - Overfishing & 3 \\
\hline * only included groups with at least five species with at least one terrestrial and one marine threat
\end{tabular}




\section{All species}

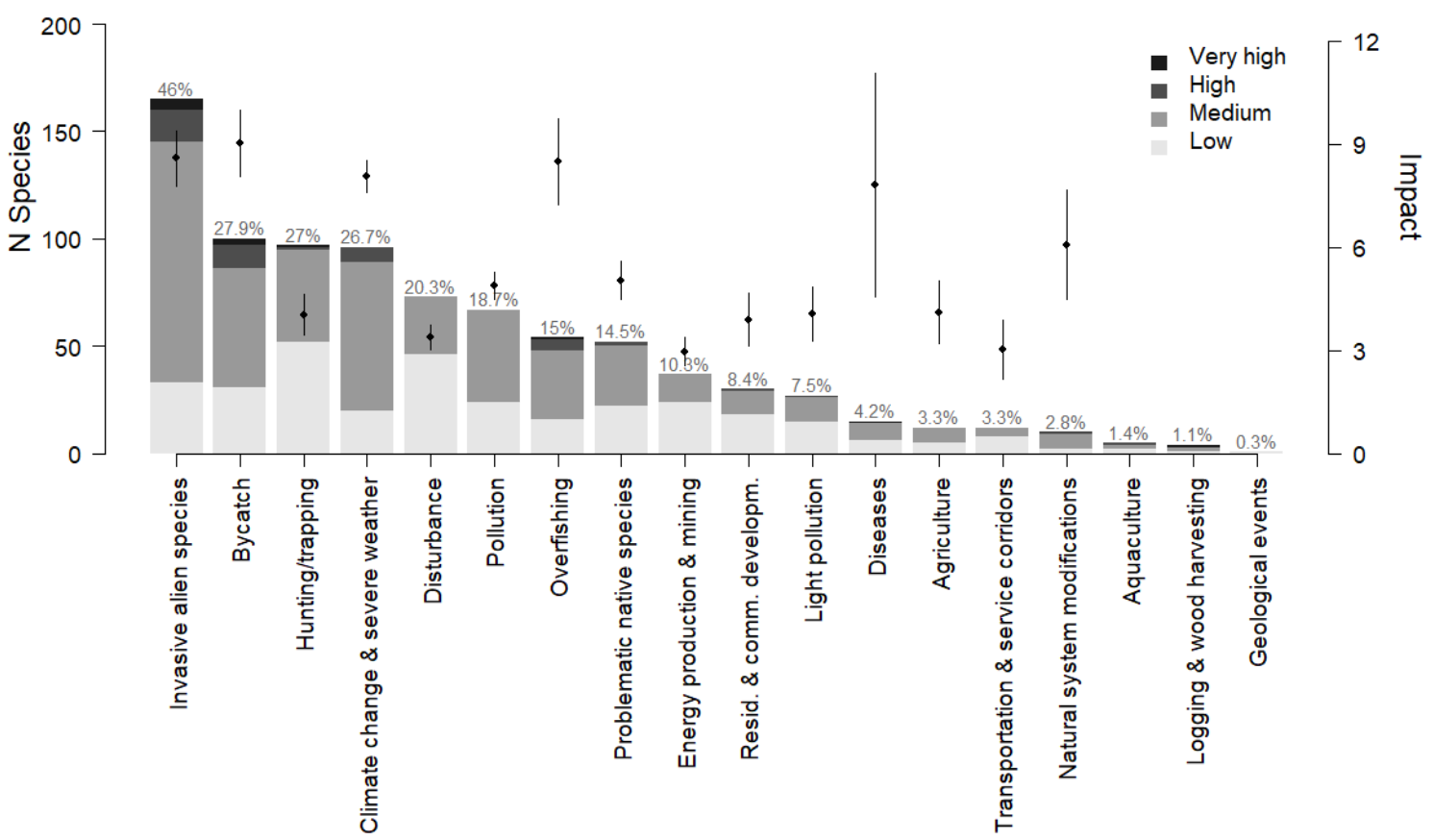

Figure 1: Ongoing threats to all seabird species (ordered by the number of species affected). Left y axis: total number of species affected; Right y axis: average impact \pm SE. Values atop bars indicate the percentage of species affected $(n=359)$. 


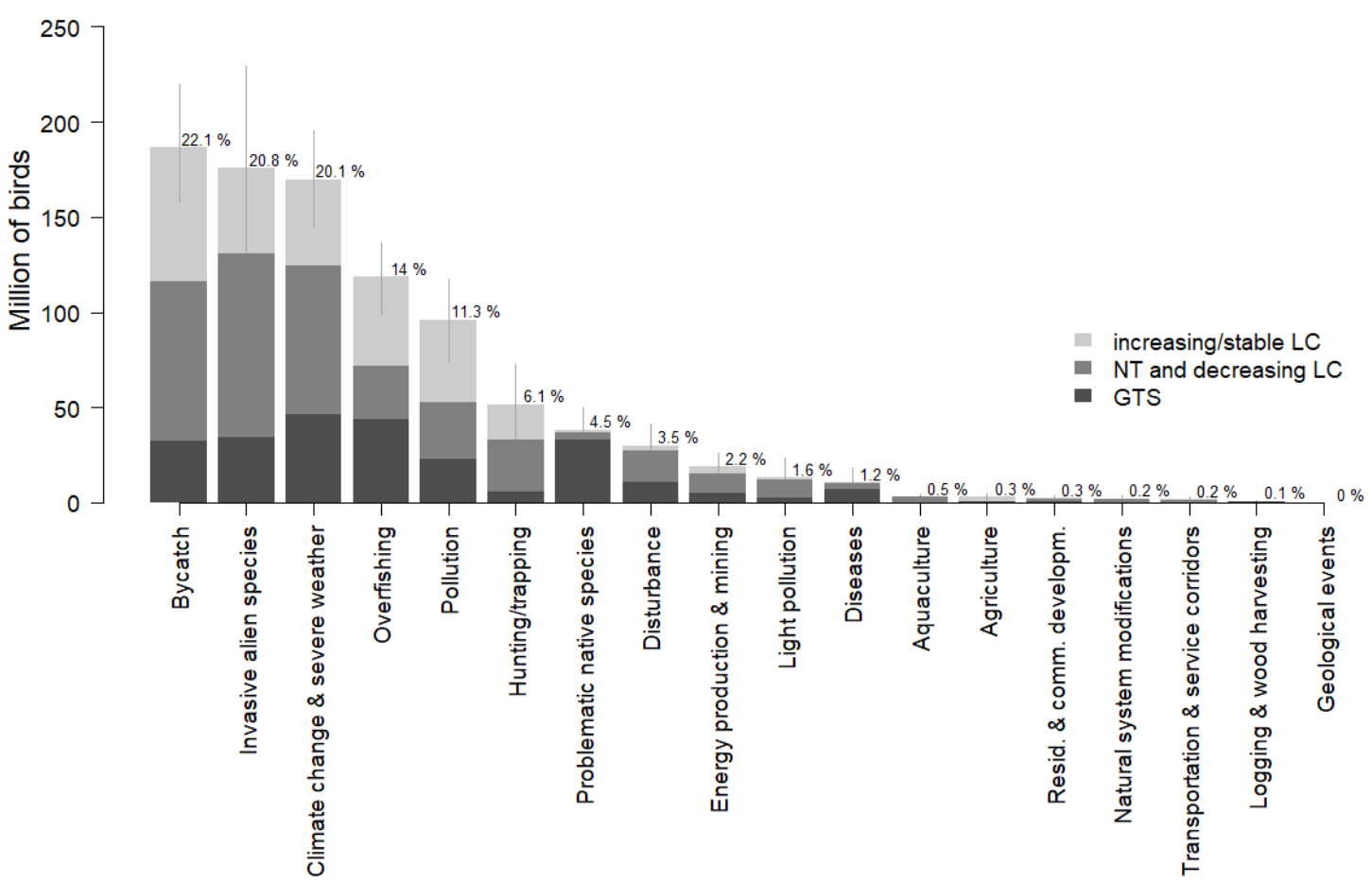

883

884

885

886

887
Figure 2: Estimated total number of seabirds exposed to each threat. Error bars represent the $95 \%$ confidence intervals (see methods). Values atop bars indicate percentage of total number of seabirds affected. 


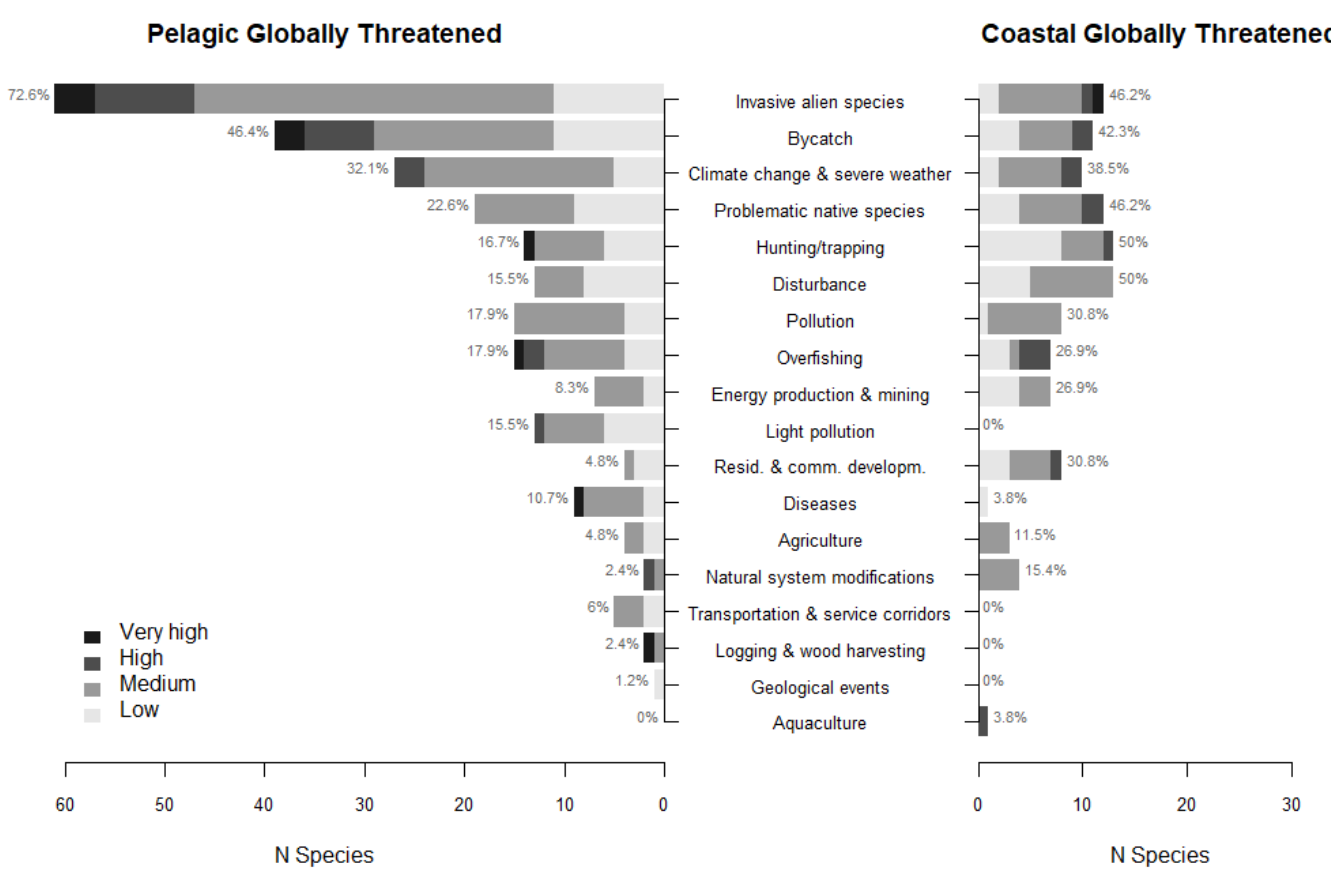

889

890 Figure 3: Ongoing threats to pelagic $(n=84)$ and coastal $(n=26)$ globally threatened seabirds; values 891 atop bars indicate percentage of species affected. 


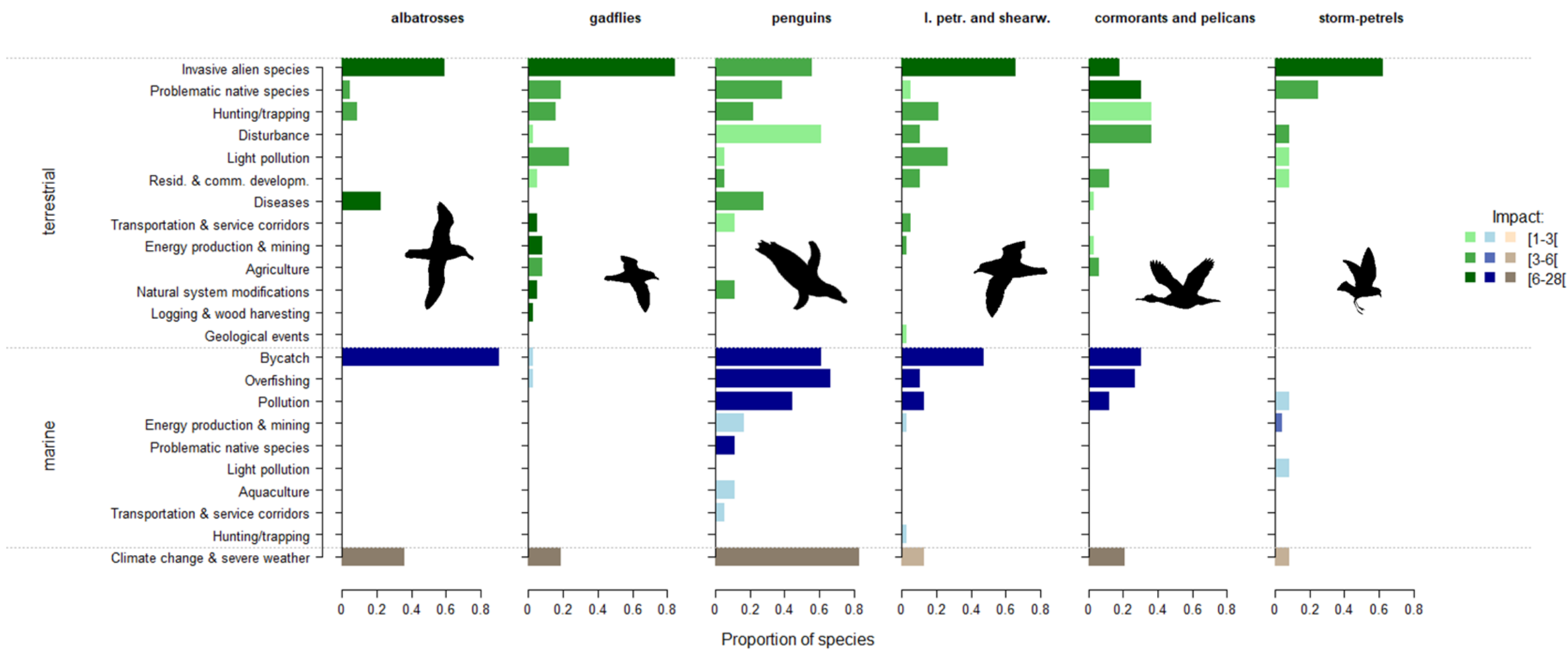

Figure 4: Main threats (split into marine and terrestrial) by group of seabird species (only groups with more than $30 \%$ of species classified as globally

threatened are shown; see also Figure A4 in Appendix 3). In column headings, I. petr. and shearw. = large petrels and shearwaters. 

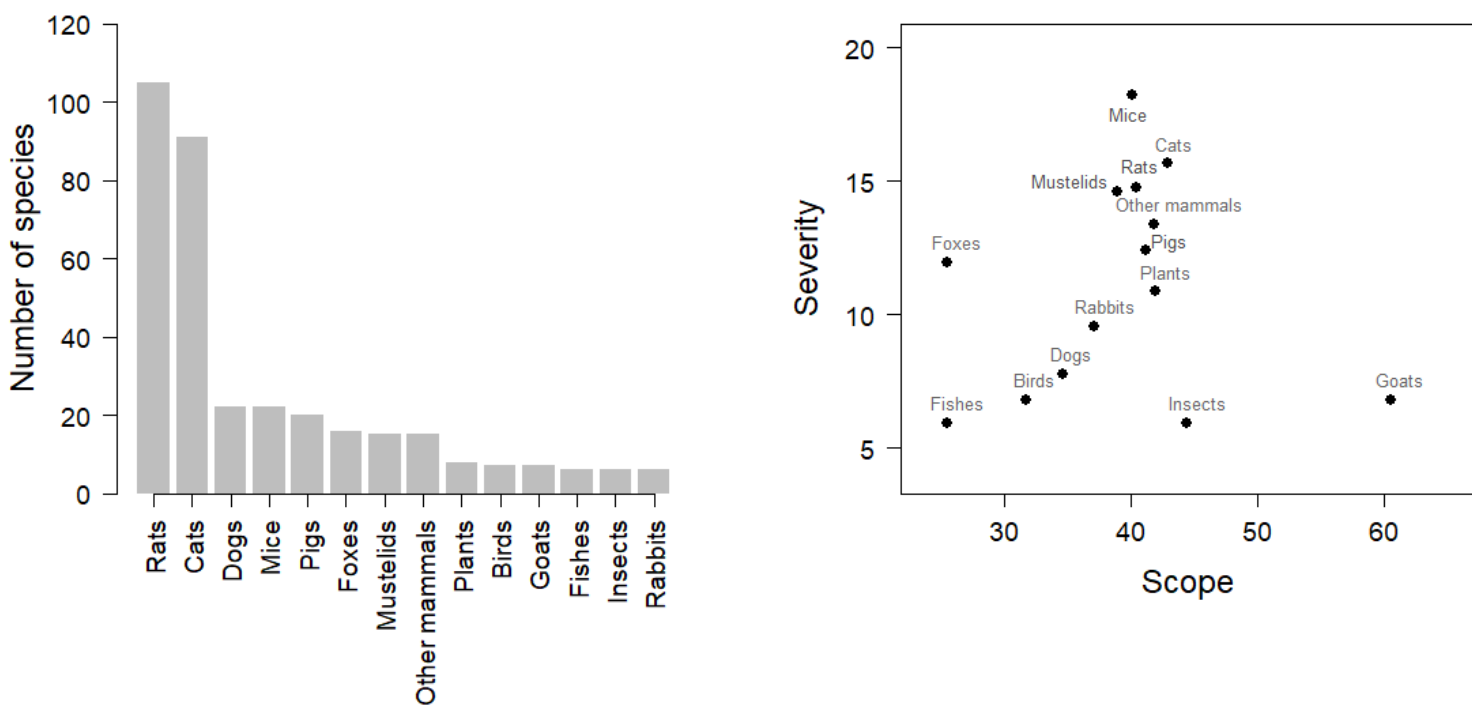

898

899 Figure 5: Left panel: number of seabird species affected by different invasive alien species. Right 900 panel: mean scope and severity of different invasive alien species. Only invasive alien species 901 affecting more than 5 seabird species are represented. 

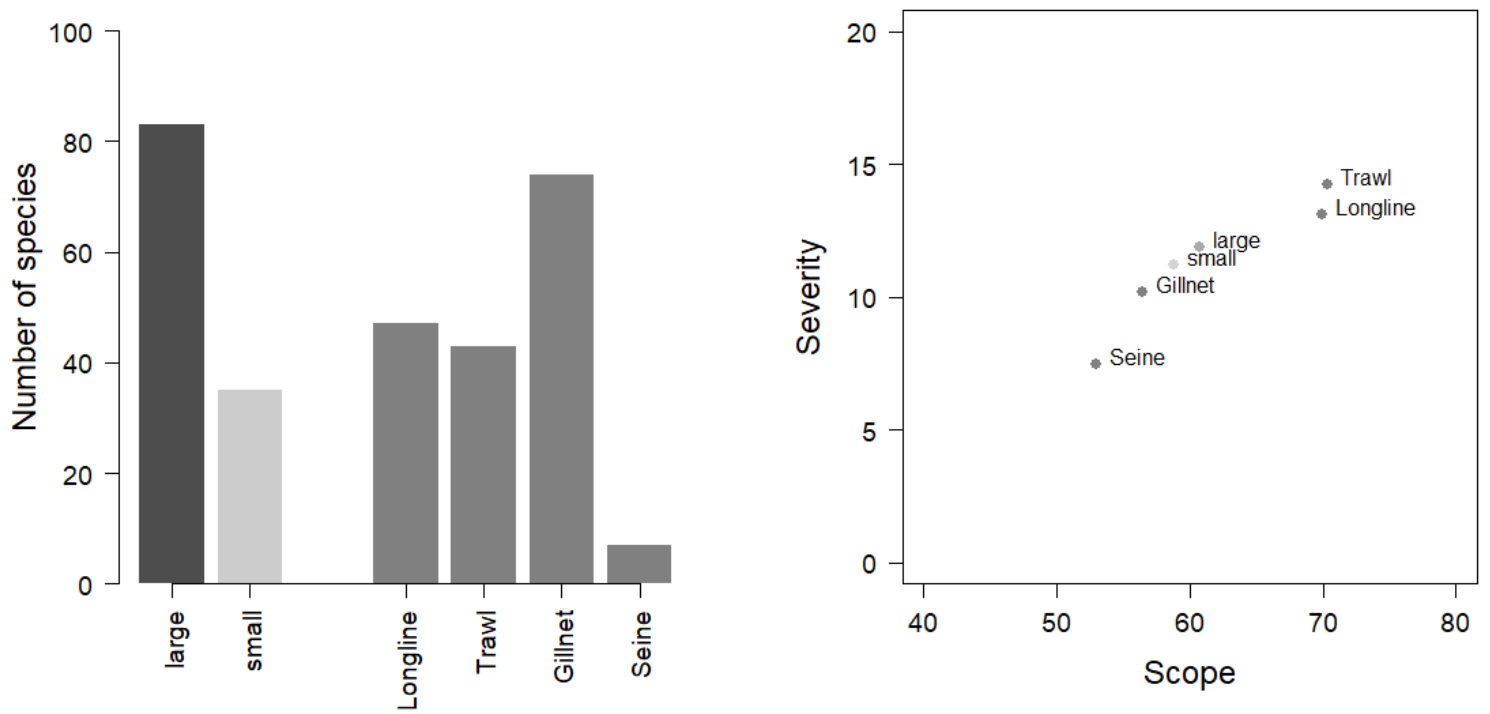

903

904 Figure 6: Left panel: Number of seabird species affected by fisheries (large vs small and different

905 gear types). Right panel: mean scope and severity of large- and small-scale fisheries and of different 906 fishing gear types. 

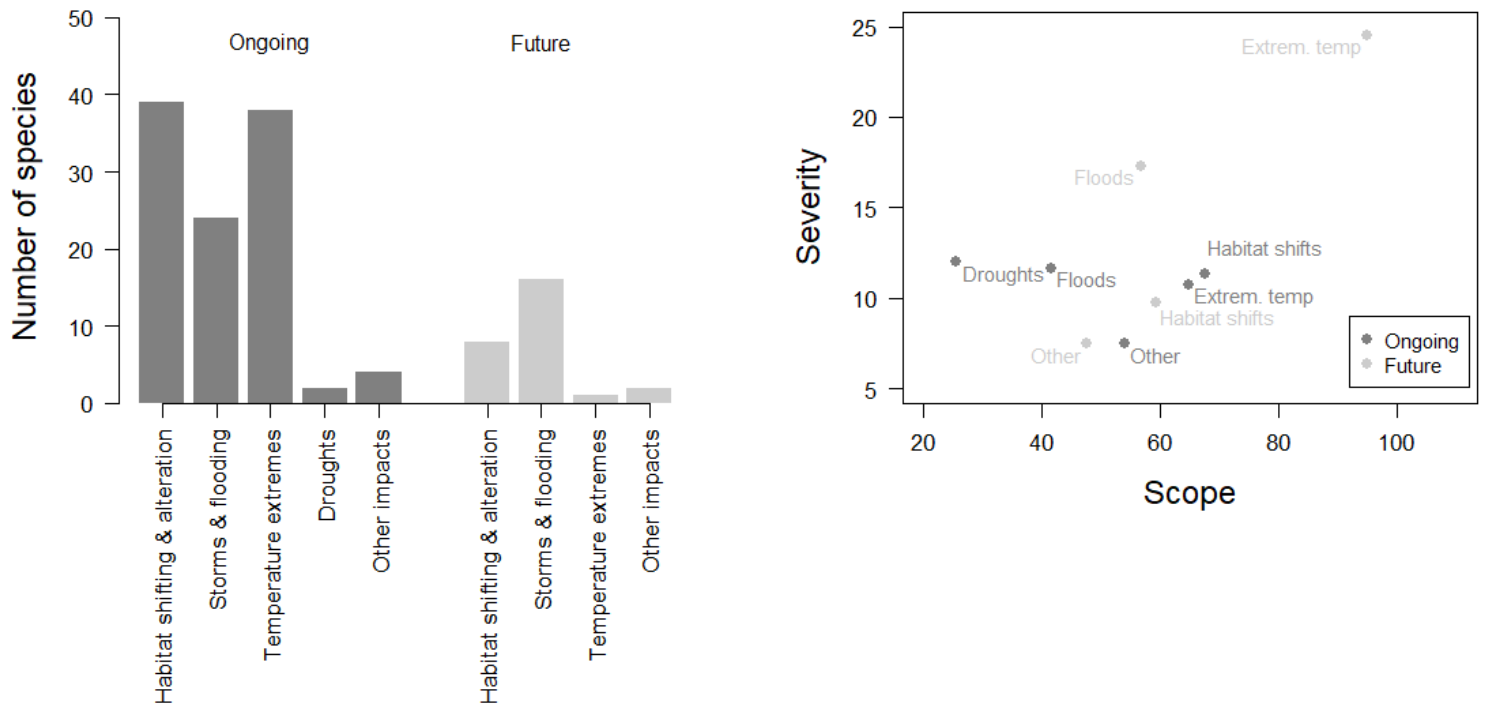

909 Figure 7: Left panel: Number of seabird species affected by different "level-2 threats" coded for the 910 threat "climate change/severe weather" (see Table A2.2, Appendix 2). Right panel: mean scope and severity of level 2 threats classified under climate change/severe weather. 


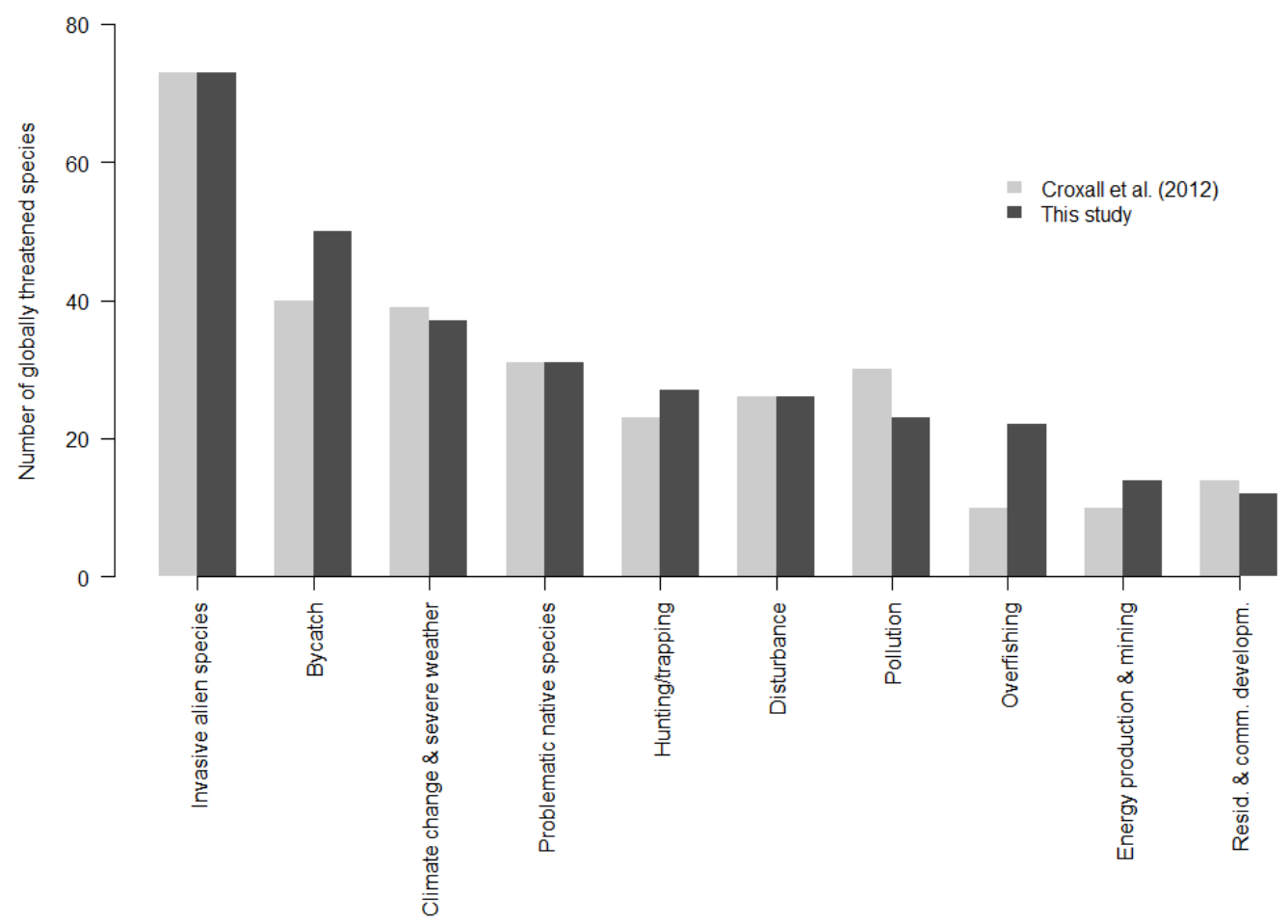

913

914 Figure 8: Comparison between the number of globally threatened seabird species affected by each 915 threat as reported by Croxall et al. (2012) and found in this study. Only threats mentioned in both 916 studies are shown. 


\section{Appendix 1: List of seabird species considered in the analysis}

919 The list follows the taxonomy adopted by BirdLife International (2018). $2018 \mathrm{IUCN}$ Red List Category: LC $=$ Least Concern, NT = Near Threatened, VU = 920 Vulnerable, $\mathrm{EN}=$ Endangered, $\mathrm{CR}=$ Critically Endangered, $\mathrm{CR}(\mathrm{PE})=$ Critically Endangered (Possibly Extinct), $\mathrm{DD}=$ Data Deficient. The classification into

921 Coastal and Pelagic is based on Croxall et al. (2012)

\begin{tabular}{|c|c|c|c|c|c|c|}
\hline Order & Family & Scientific name & Common name & $\begin{array}{c}2018 \text { IUCN Red } \\
\text { List Category }\end{array}$ & $\begin{array}{c}\text { Pelagic / } \\
\text { coastal }\end{array}$ & Group \\
\hline Anseriformes & Anatidae & Aythya marila & Greater Scaup & LC & Coastal & sea ducks and allies \\
\hline Anseriformes & Anatidae & Bucephala clangula & Common Goldeneye & LC & Coastal & sea ducks and allies \\
\hline Anseriformes & Anatidae & Bucephala islandica & Barrow's Goldeneye & LC & Coastal & sea ducks and allies \\
\hline Anseriformes & Anatidae & Clangula hyemalis & Long-tailed Duck & Vu & Coastal & sea ducks and allies \\
\hline Anseriformes & Anatidae & Histrionicus histrionicus & Harlequin Duck & LC & Coastal & sea ducks and allies \\
\hline Anseriformes & Anatidae & Melanitta americana & Black Scoter & NT & Coastal & sea ducks and allies \\
\hline Anseriformes & Anatidae & Melanitta deglandi & White-winged Scoter & LC & Coastal & sea ducks and allies \\
\hline Anseriformes & Anatidae & Melanitta fusca & Velvet Scoter & Vu & Coastal & sea ducks and allies \\
\hline Anseriformes & Anatidae & Melanitta nigra & Common Scoter & LC & Coastal & sea ducks and allies \\
\hline Anseriformes & Anatidae & Melanitta perspicillata & Surf Scoter & LC & Coastal & sea ducks and allies \\
\hline Anseriformes & Anatidae & Melanitta stejnegeri & Siberian Scoter & LC & Coastal & sea ducks and allies \\
\hline Anseriformes & Anatidae & Mergus merganser & Goosander & LC & Coastal & sea ducks and allies \\
\hline Anseriformes & Anatidae & Mergus serrator & Red-breasted Merganser & LC & Coastal & sea ducks and allies \\
\hline Anseriformes & Anatidae & Polysticta stelleri & Steller's Eider & Vu & Coastal & sea ducks and allies \\
\hline Anseriformes & Anatidae & Somateria fischeri & Spectacled Eider & NT & Coastal & sea ducks and allies \\
\hline Anseriformes & Anatidae & Somateria mollissima & Common Eider & NT & Coastal & sea ducks and allies \\
\hline Anseriformes & Anatidae & Somateria spectabilis & King Eider & LC & Coastal & sea ducks and allies \\
\hline Anseriformes & Anatidae & Tachyeres brachypterus & Falkland Steamerduck & LC & Coastal & sea ducks and allies \\
\hline Anseriformes & Anatidae & Tachyeres leucocephalus & White-headed Steamerduck & VU & Coastal & sea ducks and allies \\
\hline Anseriformes & Anatidae & Tachyeres patachonicus & Flying Steamerduck & LC & Coastal & sea ducks and allies \\
\hline Anseriformes & Anatidae & Tachyeres pteneres & Magellanic Steamerduck & LC & Coastal & sea ducks and allies \\
\hline
\end{tabular}




\begin{tabular}{|c|c|c|c|c|c|c|}
\hline Order & Family & Scientific name & Common name & $\begin{array}{c}2018 \text { IUCN Red } \\
\text { List Category }\end{array}$ & $\begin{array}{c}\text { Pelagic / } \\
\text { coastal }\end{array}$ & Group \\
\hline Charadriiformes & Alcidae & Aethia cristatella & Crested Auklet & LC & Pelagic & auks \\
\hline Charadriiformes & Alcidae & Aethia psittacula & Parakeet Auklet & LC & Pelagic & auks \\
\hline Charadriiformes & Alcidae & Aethia pusilla & Least Auklet & LC & Pelagic & auks \\
\hline Charadriiformes & Alcidae & Aethia pygmaea & Whiskered Auklet & LC & Pelagic & auks \\
\hline Charadriiformes & Alcidae & Alca torda & Razorbill & NT & Pelagic & auks \\
\hline Charadriiformes & Alcidae & Alle alle & Little Auk & LC & Pelagic & auks \\
\hline Charadriiformes & Alcidae & Brachyramphus brevirostris & Kittlitz's Murrelet & NT & Pelagic & auks \\
\hline Charadriiformes & Alcidae & Brachyramphus marmoratus & Marbled Murrelet & EN & Pelagic & auks \\
\hline Charadriiformes & Alcidae & Brachyramphus perdix & Long-billed Murrelet & NT & Pelagic & auks \\
\hline Charadriiformes & Alcidae & Cepphus carbo & Spectacled Guillemot & LC & Pelagic & auks \\
\hline Charadriiformes & Alcidae & Cepphus columba & Pigeon Guillemot & LC & Pelagic & auks \\
\hline Charadriiformes & Alcidae & Cepphus grylle & Black Guillemot & LC & Pelagic & auks \\
\hline Charadriiformes & Alcidae & Cerorhinca monocerata & Rhinoceros Auklet & LC & Pelagic & auks \\
\hline Charadriiformes & Alcidae & Fratercula arctica & Atlantic Puffin & VU & Pelagic & auks \\
\hline Charadriiformes & Alcidae & Fratercula cirrhata & Tufted Puffin & LC & Pelagic & auks \\
\hline Charadriiformes & Alcidae & Fratercula corniculata & Horned Puffin & LC & Pelagic & auks \\
\hline Charadriiformes & Alcidae & Ptychoramphus aleuticus & Cassin's Auklet & NT & Pelagic & auks \\
\hline Charadriiformes & Alcidae & Synthliboramphus antiquus & Ancient Murrelet & LC & Pelagic & auks \\
\hline Charadriiformes & Alcidae & Synthliboramphus craveri & Craveri's Murrelet & VU & Pelagic & auks \\
\hline Charadriiformes & Alcidae & Synthliboramphus hypoleucus & Guadalupe Murrelet & EN & Pelagic & auks \\
\hline Charadriiformes & Alcidae & Synthliboramphus scrippsi & Scripps's Murrelet & VU & Pelagic & auks \\
\hline Charadriiformes & Alcidae & Synthliboramphus wumizusume & Japanese Murrelet & VU & Pelagic & auks \\
\hline Charadriiformes & Alcidae & Uria aalge & Common Murre & LC & Pelagic & auks \\
\hline Charadriiformes & Alcidae & Uria lomvia & Thick-billed Murre & LC & Pelagic & auks \\
\hline Charadriiformes & Laridae & Creagrus furcatus & Swallow-tailed Gull & LC & Coastal & gulls \\
\hline Charadriiformes & Laridae & Hydrocoloeus minutus & Little Gull & LC & Coastal & gulls \\
\hline Charadriiformes & Laridae & Larus argentatus & European Herring Gull & LC & Coastal & gulls \\
\hline Charadriiformes & Laridae & Larus atlanticus & Olrog's Gull & NT & Coastal & gulls \\
\hline
\end{tabular}




\begin{tabular}{|c|c|c|c|c|c|c|}
\hline Order & Family & Scientific name & Common name & $\begin{array}{c}2018 \text { IUCN Red } \\
\text { List Category }\end{array}$ & $\begin{array}{c}\text { Pelagic / } \\
\text { coastal } \\
\end{array}$ & Group \\
\hline Charadriiformes & Laridae & Larus atricilla & Laughing Gull & LC & Coastal & gulls \\
\hline Charadriiformes & Laridae & Larus audouinii & Audouin's Gull & LC & Coastal & gulls \\
\hline Charadriiformes & Laridae & Larus belcheri & Belcher's Gull & LC & Coastal & gulls \\
\hline Charadriiformes & Laridae & Larus brunnicephalus & Brown-headed Gull & LC & Coastal & gulls \\
\hline Charadriiformes & Laridae & Larus cachinnans & Caspian Gull & LC & Coastal & gulls \\
\hline Charadriiformes & Laridae & Larus californicus & California Gull & LC & Coastal & gulls \\
\hline Charadriiformes & Laridae & Larus canus & Mew Gull & LC & Coastal & gulls \\
\hline Charadriiformes & Laridae & Larus cirrocephalus & Grey-headed Gull & LC & Coastal & gulls \\
\hline Charadriiformes & Laridae & Larus crassirostris & Black-tailed Gull & LC & Coastal & gulls \\
\hline Charadriiformes & Laridae & Larus delawarensis & Ring-billed Gull & LC & Coastal & gulls \\
\hline Charadriiformes & Laridae & Larus dominicanus & Kelp Gull & LC & Coastal & gulls \\
\hline Charadriiformes & Laridae & Larus fuliginosus & Lava Gull & VU & Coastal & gulls \\
\hline Charadriiformes & Laridae & Larus fuscus & Lesser Black-backed Gull & LC & Coastal & gulls \\
\hline Charadriiformes & Laridae & Larus genei & Slender-billed Gull & LC & Coastal & gulls \\
\hline Charadriiformes & Laridae & Larus glaucescens & Glaucous-winged Gull & LC & Coastal & gulls \\
\hline Charadriiformes & Laridae & Larus glaucoides & Iceland Gull & LC & Coastal & gulls \\
\hline Charadriiformes & Laridae & Larus hartlaubii & Hartlaub's Gull & LC & Coastal & gulls \\
\hline Charadriiformes & Laridae & Larus heermanni & Heermann's Gull & NT & Coastal & gulls \\
\hline Charadriiformes & Laridae & Larus hemprichii & Sooty Gull & LC & Coastal & gulls \\
\hline Charadriiformes & Laridae & Larus hyperboreus & Glaucous Gull & LC & Coastal & gulls \\
\hline Charadriiformes & Laridae & Larus ichthyaetus & Pallas's Gull & LC & Coastal & gulls \\
\hline Charadriiformes & Laridae & Larus leucophthalmus & White-eyed Gull & LC & Coastal & gulls \\
\hline Charadriiformes & Laridae & Larus livens & Yellow-footed Gull & LC & Coastal & gulls \\
\hline Charadriiformes & Laridae & Larus maculipennis & Brown-hooded Gull & LC & Coastal & gulls \\
\hline Charadriiformes & Laridae & Larus marinus & Great Black-backed Gull & LC & Coastal & gulls \\
\hline Charadriiformes & Laridae & Larus melanocephalus & Mediterranean Gull & LC & Coastal & gulls \\
\hline Charadriiformes & Laridae & Larus michahellis & Yellow-legged Gull & LC & Coastal & gulls \\
\hline Charadriiformes & Laridae & Larus modestus & Grey Gull & LC & Coastal & gulls \\
\hline
\end{tabular}




\begin{tabular}{|c|c|c|c|c|c|c|}
\hline Order & Family & Scientific name & Common name & $\begin{array}{c}2018 \text { IUCN Red } \\
\text { List Category }\end{array}$ & $\begin{array}{c}\text { Pelagic / } \\
\text { coastal }\end{array}$ & Group \\
\hline Charadriiformes & Laridae & Larus novaehollandiae & Silver Gull & LC & Coastal & gulls \\
\hline Charadriiformes & Laridae & Larus occidentalis & Western Gull & LC & Coastal & gulls \\
\hline Charadriiformes & Laridae & Larus pacificus & Pacific Gull & LC & Coastal & gulls \\
\hline Charadriiformes & Laridae & Larus philadelphia & Bonaparte's Gull & LC & Coastal & gulls \\
\hline Charadriiformes & Laridae & Larus pipixcan & Franklin's Gull & LC & Coastal & gulls \\
\hline Charadriiformes & Laridae & Larus ridibundus & Black-headed Gull & LC & Coastal & gulls \\
\hline Charadriiformes & Laridae & Larus schistisagus & Slaty-backed Gull & LC & Coastal & gulls \\
\hline Charadriiformes & Laridae & Larus scoresbii & Dolphin Gull & LC & Coastal & gulls \\
\hline Charadriiformes & Laridae & Larus smithsonianus & Arctic Herring Gull & LC & Coastal & gulls \\
\hline Charadriiformes & Laridae & Pagophila eburnea & Ivory Gull & NT & Coastal & gulls \\
\hline Charadriiformes & Laridae & Rhodostethia rosea & Ross's Gull & LC & Coastal & gulls \\
\hline Charadriiformes & Laridae & Rissa brevirostris & Red-legged Kittiwake & VU & Coastal & gulls \\
\hline Charadriiformes & Laridae & Rissa tridactyla & Black-legged Kittiwake & VU & Coastal & gulls \\
\hline Charadriiformes & Laridae & Saundersilarus saundersi & Saunders's Gull & VU & Coastal & gulls \\
\hline Charadriiformes & Laridae & Xema sabini & Sabine's Gull & LC & Coastal & gulls \\
\hline Charadriiformes & Scolopacidae & Phalaropus fulicarius & Red Phalarope & LC & Coastal & phalaropes \\
\hline Charadriiformes & Scolopacidae & Phalaropus lobatus & Red-necked Phalarope & LC & Coastal & phalaropes \\
\hline Charadriiformes & Stercorariidae & Catharacta antarctica & Brown Skua & LC & Pelagic & skuas \\
\hline Charadriiformes & Stercorariidae & Catharacta chilensis & Chilean Skua & LC & Pelagic & skuas \\
\hline Charadriiformes & Stercorariidae & Catharacta maccormicki & South Polar Skua & LC & Pelagic & skuas \\
\hline Charadriiformes & Stercorariidae & Catharacta skua & Great Skua & LC & Pelagic & skuas \\
\hline Charadriiformes & Stercorariidae & Stercorarius longicaudus & Long-tailed Jaeger & LC & Pelagic & skuas \\
\hline Charadriiformes & Stercorariidae & Stercorarius parasiticus & Arctic Jaeger & LC & Pelagic & skuas \\
\hline Charadriiformes & Stercorariidae & Stercorarius pomarinus & Pomarine Jaeger & LC & Pelagic & skuas \\
\hline Charadriiformes & Laridae & Anous minutus & Black Noddy & LC & Coastal & terns \\
\hline Charadriiformes & Laridae & Anous stolidus & Brown Noddy & LC & Coastal & terns \\
\hline Charadriiformes & Laridae & Anous tenuirostris & Lesser Noddy & LC & Coastal & terns \\
\hline Charadriiformes & Laridae & Chlidonias albostriatus & Black-fronted Tern & EN & Coastal & terns \\
\hline
\end{tabular}




\begin{tabular}{|c|c|c|c|c|c|c|}
\hline Order & Family & Scientific name & Common name & $\begin{array}{c}2018 \text { IUCN Red } \\
\text { List Category }\end{array}$ & $\begin{array}{c}\text { Pelagic / } \\
\text { coastal }\end{array}$ & Group \\
\hline Charadriiformes & Laridae & Chlidonias niger & Black Tern & LC & Coastal & terns \\
\hline Charadriiformes & Laridae & Gelochelidon macrotarsa & Australian Gull-billed Tern & LC & Coastal & terns \\
\hline Charadriiformes & Laridae & Gelochelidon nilotica & Common Gull-billed Tern & LC & Coastal & terns \\
\hline Charadriiformes & Laridae & Gygis alba & Common White Tern & LC & Coastal & terns \\
\hline Charadriiformes & Laridae & Gygis microrhyncha & Little White Tern & LC & Coastal & terns \\
\hline Charadriiformes & Laridae & Hydroprogne caspia & Caspian Tern & LC & Coastal & terns \\
\hline Charadriiformes & Laridae & Larosterna inca & Inca Tern & NT & Coastal & terns \\
\hline Charadriiformes & Laridae & Onychoprion aleuticus & Aleutian Tern & VU & Coastal & terns \\
\hline Charadriiformes & Laridae & Onychoprion anaethetus & Bridled Tern & LC & Coastal & terns \\
\hline Charadriiformes & Laridae & Onychoprion fuscatus & Sooty Tern & LC & Coastal & terns \\
\hline Charadriiformes & Laridae & Onychoprion lunatus & Grey-backed Tern & LC & Coastal & terns \\
\hline Charadriiformes & Laridae & Anous albivitta & Grey Noddy & LC & Coastal & terns \\
\hline Charadriiformes & Laridae & Anous cerulea & Blue Noddy & LC & Coastal & terns \\
\hline Charadriiformes & Laridae & Sterna dougallii & Roseate Tern & LC & Coastal & terns \\
\hline Charadriiformes & Laridae & Sterna forsteri & Forster's Tern & LC & Coastal & terns \\
\hline Charadriiformes & Laridae & Sterna hirundinacea & South American Tern & LC & Coastal & terns \\
\hline Charadriiformes & Laridae & Sterna hirundo & Common Tern & LC & Coastal & terns \\
\hline Charadriiformes & Laridae & Sterna paradisaea & Arctic Tern & LC & Coastal & terns \\
\hline Charadriiformes & Laridae & Sterna repressa & White-cheeked Tern & LC & Coastal & terns \\
\hline Charadriiformes & Laridae & Sterna striata & White-fronted Tern & NT & Coastal & terns \\
\hline Charadriiformes & Laridae & Sterna sumatrana & Black-naped Tern & LC & Coastal & terns \\
\hline Charadriiformes & Laridae & Sterna trudeaui & Snowy-crowned Tern & LC & Coastal & terns \\
\hline Charadriiformes & Laridae & Sterna virgata & Kerguelen Tern & NT & Coastal & terns \\
\hline Charadriiformes & Laridae & Sterna vittata & Antarctic Tern & LC & Coastal & terns \\
\hline Charadriiformes & Laridae & Sternula albifrons & Little Tern & LC & Coastal & terns \\
\hline Charadriiformes & Laridae & Sternula antillarum & Least Tern & LC & Coastal & terns \\
\hline Charadriiformes & Laridae & Sternula balaenarum & Damara Tern & VU & Coastal & terns \\
\hline Charadriiformes & Laridae & Sternula lorata & Peruvian Tern & EN & Coastal & terns \\
\hline
\end{tabular}




\begin{tabular}{|c|c|c|c|c|c|c|}
\hline Order & Family & Scientific name & Common name & $\begin{array}{c}2018 \text { IUCN Red } \\
\text { List Category }\end{array}$ & $\begin{array}{c}\text { Pelagic / } \\
\text { coastal } \\
\end{array}$ & Group \\
\hline Charadriiformes & Laridae & Sternula nereis & Fairy Tern & VU & Coastal & terns \\
\hline Charadriiformes & Laridae & Sternula saundersi & Saunders's Tern & LC & Coastal & terns \\
\hline Charadriiformes & Laridae & Thalasseus bengalensis & Lesser Crested Tern & LC & Coastal & terns \\
\hline Charadriiformes & Laridae & Thalasseus bergii & Greater Crested Tern & LC & Coastal & terns \\
\hline Charadriiformes & Laridae & Thalasseus bernsteini & Chinese Crested Tern & CR & Coastal & terns \\
\hline Charadriiformes & Laridae & Thalasseus elegans & Elegant Tern & NT & Coastal & terns \\
\hline Charadriiformes & Laridae & Thalasseus maximus & Royal Tern & LC & Coastal & terns \\
\hline Charadriiformes & Laridae & Thalasseus sandvicensis & Sandwich Tern & LC & Coastal & terns \\
\hline Gaviiformes & Gaviidae & Gavia adamsii & Yellow-billed Loon & NT & Coastal & sea ducks and allies \\
\hline Gaviiformes & Gaviidae & Gavia arctica & Arctic Loon & LC & Coastal & sea ducks and allies \\
\hline Gaviiformes & Gaviidae & Gavia immer & Common Loon & LC & Coastal & sea ducks and allies \\
\hline Gaviiformes & Gaviidae & Gavia pacifica & Pacific Loon & LC & Coastal & sea ducks and allies \\
\hline Gaviiformes & Gaviidae & Gavia stellata & Red-throated Loon & LC & Coastal & sea ducks and allies \\
\hline Pelecaniformes & Pelecanidae & Pelecanus occidentalis & Brown Pelican & LC & Coastal & cormorants and pelicans \\
\hline Pelecaniformes & Pelecanidae & Pelecanus onocrotalus & Great White Pelican & LC & Coastal & cormorants and pelicans \\
\hline Pelecaniformes & Pelecanidae & Pelecanus thagus & Peruvian Pelican & NT & Pelagic & cormorants and pelicans \\
\hline Phaethontiformes & Phaethontidae & Phaethon aethereus & Red-billed Tropicbird & LC & Pelagic & frigatebirds and tropicbirds \\
\hline Phaethontiformes & Phaethontidae & Phaethon lepturus & White-tailed Tropicbird & LC & Pelagic & frigatebirds and tropicbirds \\
\hline Phaethontiformes & Phaethontidae & Phaethon rubricauda & Red-tailed Tropicbird & LC & Pelagic & frigatebirds and tropicbirds \\
\hline Podicipediformes & Podicipedidae & Podiceps auritus & Horned Grebe & VU & Coastal & sea ducks and allies \\
\hline Podicipediformes & Podicipedidae & Podiceps cristatus & Great Crested Grebe & LC & Coastal & sea ducks and allies \\
\hline Podicipediformes & Podicipedidae & Podiceps grisegena & Red-necked Grebe & LC & Coastal & sea ducks and allies \\
\hline Podicipediformes & Podicipedidae & Podiceps nigricollis & Black-necked Grebe & LC & Coastal & sea ducks and allies \\
\hline Procellariiformes & Diomedeidae & Diomedea amsterdamensis & Amsterdam Albatross & EN & Pelagic & albatrosses \\
\hline Procellariiformes & Diomedeidae & Diomedea antipodensis & Antipodean Albatross & EN & Pelagic & albatrosses \\
\hline Procellariiformes & Diomedeidae & Diomedea dabbenena & Tristan Albatross & CR & Pelagic & albatrosses \\
\hline Procellariiformes & Diomedeidae & Diomedea epomophora & Southern Royal Albatross & VU & Pelagic & albatrosses \\
\hline Procellariiformes & Diomedeidae & Diomedea exulans & Wandering Albatross & vu & Pelagic & albatrosses \\
\hline
\end{tabular}




\begin{tabular}{|c|c|c|c|c|c|c|}
\hline Order & Family & Scientific name & Common name & $\begin{array}{l}2018 \text { IUCN Red } \\
\text { List Category }\end{array}$ & $\begin{array}{c}\text { Pelagic / } \\
\text { coastal } \\
\end{array}$ & Group \\
\hline Procellariiformes & Diomedeidae & Diomedea sanfordi & Northern Royal Albatross & EN & Pelagic & albatrosses \\
\hline Procellariiformes & Diomedeidae & Phoebastria albatrus & Short-tailed Albatross & $\mathrm{Vu}$ & Pelagic & albatrosses \\
\hline Procellariiformes & Diomedeidae & Phoebastria immutabilis & Laysan Albatross & NT & Pelagic & albatrosses \\
\hline Procellariiformes & Diomedeidae & Phoebastria irrorata & Waved Albatross & CR & Pelagic & albatrosses \\
\hline Procellariiformes & Diomedeidae & Phoebastria nigripes & Black-footed Albatross & NT & Pelagic & albatrosses \\
\hline Procellariiformes & Diomedeidae & Phoebetria fusca & Sooty Albatross & EN & Pelagic & albatrosses \\
\hline Procellariiformes & Diomedeidae & Phoebetria palpebrata & Light-mantled Albatross & NT & Pelagic & albatrosses \\
\hline Procellariiformes & Diomedeidae & Thalassarche bulleri & Buller's Albatross & NT & Pelagic & albatrosses \\
\hline Procellariiformes & Diomedeidae & Thalassarche carteri & Indian Yellow-nosed Albatross & EN & Pelagic & albatrosses \\
\hline Procellariiformes & Diomedeidae & Thalassarche cauta & Shy Albatross & NT & Pelagic & albatrosses \\
\hline Procellariiformes & Diomedeidae & Thalassarche chlororhynchos & Atlantic Yellow-nosed Albatross & EN & Pelagic & albatrosses \\
\hline Procellariiformes & Diomedeidae & Thalassarche chrysostoma & Grey-headed Albatross & EN & Pelagic & albatrosses \\
\hline Procellariiformes & Diomedeidae & Thalassarche eremita & Chatham Albatross & VU & Pelagic & albatrosses \\
\hline Procellariiformes & Diomedeidae & Thalassarche impavida & Campbell Albatross & VU & Pelagic & albatrosses \\
\hline Procellariiformes & Diomedeidae & Thalassarche melanophris & Black-browed Albatross & LC & Pelagic & albatrosses \\
\hline Procellariiformes & Diomedeidae & Thalassarche salvini & Salvin's Albatross & VU & Pelagic & albatrosses \\
\hline Procellariiformes & Diomedeidae & Thalassarche steadi & White-capped Albatross & NT & Pelagic & albatrosses \\
\hline Procellariiformes & Procellariidae & Pseudobulweria aterrima & Mascarene Petrel & CR & Pelagic & gadflies \\
\hline Procellariiformes & Procellariidae & Pseudobulweria becki & Beck's Petrel & CR & Pelagic & gadflies \\
\hline Procellariiformes & Procellariidae & Pseudobulweria macgillivrayi & Fiji Petrel & CR & Pelagic & gadflies \\
\hline Procellariiformes & Procellariidae & Pseudobulweria rostrata & Tahiti Petrel & NT & Pelagic & gadflies \\
\hline Procellariiformes & Procellariidae & Pterodroma alba & Phoenix Petrel & EN & Pelagic & gadflies \\
\hline Procellariiformes & Procellariidae & Pterodroma arminjoniana & Trindade Petrel & $\mathrm{Vu}$ & Pelagic & gadflies \\
\hline Procellariiformes & Procellariidae & Pterodroma atrata & Henderson Petrel & EN & Pelagic & gadflies \\
\hline Procellariiformes & Procellariidae & Pterodroma axillaris & Chatham Petrel & VU & Pelagic & gadflies \\
\hline Procellariiformes & Procellariidae & Pterodroma baraui & Barau's Petrel & EN & Pelagic & gadflies \\
\hline Procellariiformes & Procellariidae & Pterodroma brevipes & Collared Petrel & VU & Pelagic & gadflies \\
\hline Procellariiformes & Procellariidae & Pterodroma cahow & Bermuda Petrel & EN & Pelagic & gadflies \\
\hline
\end{tabular}




\begin{tabular}{|c|c|c|c|c|c|c|}
\hline Order & Family & Scientific name & Common name & $\begin{array}{l}2018 \text { IUCN Red } \\
\text { List Category }\end{array}$ & $\begin{array}{l}\text { Pelagic / } \\
\text { coastal }\end{array}$ & Group \\
\hline Procellariiformes & Procellariidae & Pterodroma caribbaea & Jamaican Petrel & $\mathrm{CR}(\mathrm{PE})$ & Pelagic & gadflies \\
\hline Procellariiformes & Procellariidae & Pterodroma cervicalis & White-necked Petrel & VU & Pelagic & gadflies \\
\hline Procellariiformes & Procellariidae & Pterodroma cookii & Cook's Petrel & VU & Pelagic & gadflies \\
\hline Procellariiformes & Procellariidae & Pterodroma defilippiana & Masatierra Petrel & VU & Pelagic & gadflies \\
\hline Procellariiformes & Procellariidae & Pterodroma deserta & Desertas Petrel & VU & Pelagic & gadflies \\
\hline Procellariiformes & Procellariidae & Pterodroma externa & Juan Fernandez Petrel & VU & Pelagic & gadflies \\
\hline Procellariiformes & Procellariidae & Pterodroma feae & Cape Verde Petrel & NT & Pelagic & gadflies \\
\hline Procellariiformes & Procellariidae & Pterodroma gouldi & Grey-faced Petrel & LC & Pelagic & gadflies \\
\hline Procellariiformes & Procellariidae & Pterodroma hasitata & Black-capped Petrel & EN & Pelagic & gadflies \\
\hline Procellariiformes & Procellariidae & Pterodroma heraldica & Herald Petrel & LC & Pelagic & gadflies \\
\hline Procellariiformes & Procellariidae & Pterodroma hypoleuca & Bonin Petrel & LC & Pelagic & gadflies \\
\hline Procellariiformes & Procellariidae & Pterodroma incerta & Atlantic Petrel & EN & Pelagic & gadflies \\
\hline Procellariiformes & Procellariidae & Pterodroma inexpectata & Mottled Petrel & NT & Pelagic & gadflies \\
\hline Procellariiformes & Procellariidae & Pterodroma lessonii & White-headed Petrel & LC & Pelagic & gadflies \\
\hline Procellariiformes & Procellariidae & Pterodroma leucoptera & White-winged Petrel & VU & Pelagic & gadflies \\
\hline Procellariiformes & Procellariidae & Pterodroma longirostris & Stejneger's Petrel & VU & Pelagic & gadflies \\
\hline Procellariiformes & Procellariidae & Pterodroma macroptera & Great-winged Petrel & LC & Pelagic & gadflies \\
\hline Procellariiformes & Procellariidae & Pterodroma madeira & Zino's Petrel & EN & Pelagic & gadflies \\
\hline Procellariiformes & Procellariidae & Pterodroma magentae & Magenta Petrel & $\mathrm{CR}$ & Pelagic & gadflies \\
\hline Procellariiformes & Procellariidae & Pterodroma mollis & Soft-plumaged Petrel & LC & Pelagic & gadflies \\
\hline Procellariiformes & Procellariidae & Pterodroma neglecta & Kermadec Petrel & LC & Pelagic & gadflies \\
\hline Procellariiformes & Procellariidae & Pterodroma nigripennis & Black-winged Petrel & LC & Pelagic & gadflies \\
\hline Procellariiformes & Procellariidae & Pterodroma phaeopygia & Galapagos Petrel & $C R$ & Pelagic & gadflies \\
\hline Procellariiformes & Procellariidae & Pterodroma pycrofti & Pycroft's Petrel & VU & Pelagic & gadflies \\
\hline Procellariiformes & Procellariidae & Pterodroma sandwichensis & Hawaiian Petrel & EN & Pelagic & gadflies \\
\hline Procellariiformes & Procellariidae & Pterodroma solandri & Providence Petrel & VU & Pelagic & gadflies \\
\hline Procellariiformes & Procellariidae & Pterodroma ultima & Murphy's Petrel & NT & Pelagic & gadflies \\
\hline Procellariiformes & Procellariidae & Ardenna bulleri & Buller's Shearwater & vu & Pelagic & large petrels and shearwaters \\
\hline
\end{tabular}




\begin{tabular}{|c|c|c|c|c|c|c|}
\hline Order & Family & Scientific name & Common name & $\begin{array}{l}2018 \text { IUCN Red } \\
\text { List Category }\end{array}$ & $\begin{array}{l}\text { Pelagic / } \\
\text { coastal }\end{array}$ & Group \\
\hline Procellariiformes & Procellariidae & Ardenna carneipes & Flesh-footed Shearwater & NT & Pelagic & large petrels and shearwaters \\
\hline Procellariiformes & Procellariidae & Ardenna creatopus & Pink-footed Shearwater & VU & Pelagic & large petrels and shearwaters \\
\hline Procellariiformes & Procellariidae & Ardenna gravis & Great Shearwater & LC & Pelagic & large petrels and shearwaters \\
\hline Procellariiformes & Procellariidae & Ardenna grisea & Sooty Shearwater & NT & Pelagic & large petrels and shearwaters \\
\hline Procellariiformes & Procellariidae & Ardenna pacifica & Wedge-tailed Shearwater & LC & Pelagic & large petrels and shearwaters \\
\hline Procellariiformes & Procellariidae & Ardenna tenuirostris & Short-tailed Shearwater & LC & Pelagic & large petrels and shearwaters \\
\hline Procellariiformes & Procellariidae & Calonectris borealis & Cory's Shearwater & LC & Pelagic & large petrels and shearwaters \\
\hline Procellariiformes & Procellariidae & Calonectris diomedea & Scopoli's Shearwater & LC & Pelagic & large petrels and shearwaters \\
\hline Procellariiformes & Procellariidae & Calonectris edwardsii & Cape Verde Shearwater & NT & Pelagic & large petrels and shearwaters \\
\hline Procellariiformes & Procellariidae & Calonectris leucomelas & Streaked Shearwater & NT & Pelagic & large petrels and shearwaters \\
\hline Procellariiformes & Procellariidae & Fulmarus glacialis & Northern Fulmar & LC & Pelagic & large petrels and shearwaters \\
\hline Procellariiformes & Procellariidae & Fulmarus glacialoides & Southern Fulmar & LC & Pelagic & large petrels and shearwaters \\
\hline Procellariiformes & Procellariidae & Macronectes giganteus & Southern Giant Petrel & LC & Pelagic & large petrels and shearwaters \\
\hline Procellariiformes & Procellariidae & Macronectes halli & Northern Giant Petrel & LC & Pelagic & large petrels and shearwaters \\
\hline Procellariiformes & Procellariidae & Procellaria aequinoctialis & White-chinned Petrel & VU & Pelagic & large petrels and shearwaters \\
\hline Procellariiformes & Procellariidae & Procellaria cinerea & Grey Petrel & NT & Pelagic & large petrels and shearwaters \\
\hline Procellariiformes & Procellariidae & Procellaria conspicillata & Spectacled Petrel & VU & Pelagic & large petrels and shearwaters \\
\hline Procellariiformes & Procellariidae & Procellaria parkinsoni & Black Petrel & VU & Pelagic & large petrels and shearwaters \\
\hline Procellariiformes & Procellariidae & Procellaria westlandica & Westland Petrel & EN & Pelagic & large petrels and shearwaters \\
\hline Procellariiformes & Procellariidae & Puffinus assimilis & Little Shearwater & LC & Pelagic & large petrels and shearwaters \\
\hline Procellariiformes & Procellariidae & Puffinus auricularis & Townsend's Shearwater & $C R$ & Pelagic & large petrels and shearwaters \\
\hline Procellariiformes & Procellariidae & Puffinus bailloni & Tropical Shearwater & LC & Pelagic & large petrels and shearwaters \\
\hline Procellariiformes & Procellariidae & Puffinus bannermani & Bannerman's Shearwater & EN & Pelagic & large petrels and shearwaters \\
\hline Procellariiformes & Procellariidae & Puffinus bryani & Bryan's Shearwater & $C R$ & Pelagic & large petrels and shearwaters \\
\hline Procellariiformes & Procellariidae & Puffinus elegans & Subantarctic Shearwater & LC & Pelagic & large petrels and shearwaters \\
\hline Procellariiformes & Procellariidae & Puffinus gavia & Fluttering Shearwater & LC & Pelagic & large petrels and shearwaters \\
\hline Procellariiformes & Procellariidae & Puffinus heinrothi & Heinroth's Shearwater & VU & Pelagic & large petrels and shearwaters \\
\hline Procellariiformes & Procellariidae & Puffinus huttoni & Hutton's Shearwater & EN & Pelagic & large petrels and shearwaters \\
\hline
\end{tabular}




\begin{tabular}{|c|c|c|c|c|c|c|}
\hline Order & Family & Scientific name & Common name & $\begin{array}{l}2018 \text { IUCN Red } \\
\text { List Category }\end{array}$ & $\begin{array}{c}\text { Pelagic / } \\
\text { coastal }\end{array}$ & Group \\
\hline Procellariiformes & Procellariidae & Puffinus Iherminieri & Audubon's Shearwater & LC & Pelagic & large petrels and shearwaters \\
\hline Procellariiformes & Procellariidae & Puffinus mauretanicus & Balearic Shearwater & $\mathrm{CR}$ & Pelagic & large petrels and shearwaters \\
\hline Procellariiformes & Procellariidae & Puffinus nativitatis & Christmas Shearwater & LC & Pelagic & large petrels and shearwaters \\
\hline Procellariiformes & Procellariidae & Puffinus newelli & Newell's Shearwater & CR & Pelagic & large petrels and shearwaters \\
\hline Procellariiformes & Procellariidae & Puffinus opisthomelas & Black-vented Shearwater & NT & Pelagic & large petrels and shearwaters \\
\hline Procellariiformes & Procellariidae & Puffinus persicus & Persian Shearwater & LC & Pelagic & large petrels and shearwaters \\
\hline Procellariiformes & Procellariidae & Puffinus puffinus & Manx Shearwater & LC & Pelagic & large petrels and shearwaters \\
\hline Procellariiformes & Procellariidae & Puffinus subalaris & Galapagos Shearwater & LC & Pelagic & large petrels and shearwaters \\
\hline Procellariiformes & Procellariidae & Puffinus yelkouan & Yelkouan Shearwater & VU & Pelagic & large petrels and shearwaters \\
\hline Procellariiformes & Procellariidae & Aphrodroma brevirostris & Kerguelen Petrel & LC & Pelagic & small petrels \\
\hline Procellariiformes & Procellariidae & Bulweria bulwerii & Bulwer's Petrel & LC & Pelagic & small petrels \\
\hline Procellariiformes & Procellariidae & Bulweria fallax & Jouanin's Petrel & NT & Pelagic & small petrels \\
\hline Procellariiformes & Procellariidae & Daption capense & Cape Petrel & LC & Pelagic & small petrels \\
\hline Procellariiformes & Procellariidae & Halobaena caerulea & Blue Petrel & LC & Pelagic & small petrels \\
\hline Procellariiformes & Procellariidae & Pachyptila belcheri & Slender-billed Prion & LC & Pelagic & small petrels \\
\hline Procellariiformes & Procellariidae & Pachyptila crassirostris & Fulmar Prion & LC & Pelagic & small petrels \\
\hline Procellariiformes & Procellariidae & Pachyptila desolata & Antarctic Prion & LC & Pelagic & small petrels \\
\hline Procellariiformes & Procellariidae & Pachyptila macgillivrayi & MacGillivray's Prion & EN & Pelagic & small petrels \\
\hline Procellariiformes & Procellariidae & Pachyptila salvini & Salvin's Prion & LC & Pelagic & small petrels \\
\hline Procellariiformes & Procellariidae & Pachyptila turtur & Fairy Prion & LC & Pelagic & small petrels \\
\hline Procellariiformes & Procellariidae & Pachyptila vittata & Broad-billed Prion & LC & Pelagic & small petrels \\
\hline Procellariiformes & Procellariidae & Pagodroma nivea & Snow Petrel & LC & Pelagic & small petrels \\
\hline Procellariiformes & Procellariidae & Pelecanoides garnotii & Peruvian Diving-petrel & EN & Pelagic & small petrels \\
\hline Procellariiformes & Procellariidae & Pelecanoides georgicus & South Georgia Diving-petrel & LC & Pelagic & small petrels \\
\hline Procellariiformes & Procellariidae & Pelecanoides magellani & Magellanic Diving-petrel & LC & Pelagic & small petrels \\
\hline Procellariiformes & Procellariidae & Pelecanoides urinatrix & Common Diving-petrel & LC & Pelagic & small petrels \\
\hline Procellariiformes & Procellariidae & Thalassoica antarctica & Antarctic Petrel & LC & Pelagic & small petrels \\
\hline Procellariiformes & Oceanitidae & Fregetta grallaria & White-bellied Storm-petrel & LC & Pelagic & storm-petrels \\
\hline
\end{tabular}




\begin{tabular}{|c|c|c|c|c|c|c|}
\hline Order & Family & Scientific name & Common name & $\begin{array}{c}2018 \text { IUCN Red } \\
\text { List Category }\end{array}$ & $\begin{array}{c}\begin{array}{c}\text { Pelagic / } \\
\text { coastal }\end{array} \\
\end{array}$ & Group \\
\hline Procellariiformes & Oceanitidae & Fregetta maoriana & New Zealand Storm-petrel & CR & Pelagic & storm-petrels \\
\hline Procellariiformes & Oceanitidae & Fregetta tropica & Black-bellied Storm-petrel & LC & Pelagic & storm-petrels \\
\hline Procellariiformes & Oceanitidae & Garrodia nereis & Grey-backed Storm-petrel & LC & Pelagic & storm-petrels \\
\hline Procellariiformes & Hydrobatidae & Hydrobates castro & Band-rumped Storm-petrel & LC & Pelagic & storm-petrels \\
\hline Procellariiformes & Hydrobatidae & Hydrobates furcatus & Fork-tailed Storm-petrel & LC & Pelagic & storm-petrels \\
\hline Procellariiformes & Hydrobatidae & Hydrobates homochroa & Ashy Storm-petrel & EN & Pelagic & storm-petrels \\
\hline Procellariiformes & Hydrobatidae & Hydrobates hornbyi & Ringed Storm-petrel & $\mathrm{DD}$ & Pelagic & storm-petrels \\
\hline Procellariiformes & Hydrobatidae & Hydrobates leucorhous & Leach's Storm-petrel & VU & Pelagic & storm-petrels \\
\hline Procellariiformes & Hydrobatidae & Hydrobates macrodactylus & Guadalupe Storm-petrel & $\mathrm{CR}(\mathrm{PE})$ & Pelagic & storm-petrels \\
\hline Procellariiformes & Hydrobatidae & Hydrobates markhami & Markham's Storm-petrel & $\mathrm{DD}$ & Pelagic & storm-petrels \\
\hline Procellariiformes & Hydrobatidae & Hydrobates matsudairae & Matsudaira's Storm-petrel & VU & Pelagic & storm-petrels \\
\hline Procellariiformes & Hydrobatidae & Hydrobates melania & Black Storm-petrel & LC & Pelagic & storm-petrels \\
\hline Procellariiformes & Hydrobatidae & Hydrobates microsoma & Least Storm-petrel & LC & Pelagic & storm-petrels \\
\hline Procellariiformes & Hydrobatidae & Hydrobates monorhis & Swinhoe's Storm-petrel & NT & Pelagic & storm-petrels \\
\hline Procellariiformes & Hydrobatidae & Hydrobates monteiroi & Monteiro's Storm-petrel & VU & Pelagic & storm-petrels \\
\hline Procellariiformes & Hydrobatidae & Hydrobates pelagicus & European Storm-petrel & LC & Pelagic & storm-petrels \\
\hline Procellariiformes & Hydrobatidae & Hydrobates tethys & Wedge-rumped Storm-petrel & LC & Pelagic & storm-petrels \\
\hline Procellariiformes & Hydrobatidae & Hydrobates tristrami & Tristram's Storm-petrel & NT & Pelagic & storm-petrels \\
\hline Procellariiformes & Oceanitidae & Nesofregetta fuliginosa & Polynesian Storm-petrel & EN & Pelagic & storm-petrels \\
\hline Procellariiformes & Oceanitidae & Oceanites gracilis & White-vented Storm-petrel & $\mathrm{DD}$ & Pelagic & storm-petrels \\
\hline Procellariiformes & Oceanitidae & Oceanites oceanicus & Wilson's Storm-petrel & LC & Pelagic & storm-petrels \\
\hline Procellariiformes & Oceanitidae & Oceanites pincoyae & Pincoya Storm-petrel & $\mathrm{DD}$ & Pelagic & storm-petrels \\
\hline Procellariiformes & Oceanitidae & Pelagodroma marina & White-faced Storm-petrel & LC & Pelagic & storm-petrels \\
\hline Sphenisciformes & Spheniscidae & Aptenodytes forsteri & Emperor Penguin & NT & Pelagic & penguins \\
\hline Sphenisciformes & Spheniscidae & Aptenodytes patagonicus & King Penguin & LC & Pelagic & penguins \\
\hline Sphenisciformes & Spheniscidae & Eudyptes chrysocome & Southern Rockhopper Penguin & Vu & Pelagic & penguins \\
\hline Sphenisciformes & Spheniscidae & Eudyptes chrysolophus & Macaroni Penguin & VU & Pelagic & penguins \\
\hline Sphenisciformes & Spheniscidae & Eudyptes moseleyi & Northern Rockhopper Penguin & EN & Pelagic & penguins \\
\hline
\end{tabular}




\begin{tabular}{|c|c|c|c|c|c|c|}
\hline Order & Family & Scientific name & Common name & $\begin{array}{c}2018 \text { IUCN Red } \\
\text { List Category }\end{array}$ & $\begin{array}{c}\text { Pelagic / } \\
\text { coastal }\end{array}$ & Group \\
\hline Sphenisciformes & Spheniscidae & Eudyptes pachyrhynchus & Fiordland Penguin & VU & Pelagic & penguins \\
\hline Sphenisciformes & Spheniscidae & Eudyptes robustus & Snares Penguin & Vu & Pelagic & penguins \\
\hline Sphenisciformes & Spheniscidae & Eudyptes schlegeli & Royal Penguin & NT & Pelagic & penguins \\
\hline Sphenisciformes & Spheniscidae & Eudyptes sclateri & Erect-crested Penguin & EN & Pelagic & penguins \\
\hline Sphenisciformes & Spheniscidae & Eudyptula minor & Little Penguin & LC & Pelagic & penguins \\
\hline Sphenisciformes & Spheniscidae & Megadyptes antipodes & Yellow-eyed Penguin & EN & Pelagic & penguins \\
\hline Sphenisciformes & Spheniscidae & Pygoscelis adeliae & Adélie Penguin & LC & Pelagic & penguins \\
\hline Sphenisciformes & Spheniscidae & Pygoscelis antarcticus & Chinstrap Penguin & LC & Pelagic & penguins \\
\hline Sphenisciformes & Spheniscidae & Pygoscelis papua & Gentoo Penguin & LC & Pelagic & penguins \\
\hline Sphenisciformes & Spheniscidae & Spheniscus demersus & African Penguin & EN & Pelagic & penguins \\
\hline Sphenisciformes & Spheniscidae & Spheniscus humboldti & Humboldt Penguin & VU & Pelagic & penguins \\
\hline Sphenisciformes & Spheniscidae & Spheniscus magellanicus & Magellanic Penguin & NT & Pelagic & penguins \\
\hline Sphenisciformes & Spheniscidae & Spheniscus mendiculus & Galapagos Penguin & EN & Pelagic & penguins \\
\hline Suliformes & Phalacrocoracidae & Gulosus aristotelis & European Shag & LC & Coastal & cormorants and pelicans \\
\hline Suliformes & Phalacrocoracidae & Leucocarbo atriceps & Imperial Shag & LC & Coastal & cormorants and pelicans \\
\hline Suliformes & Phalacrocoracidae & Leucocarbo bougainvilliorum & Guanay Cormorant & NT & Coastal & cormorants and pelicans \\
\hline Suliformes & Phalacrocoracidae & Leucocarbo campbelli & Campbell Shag & VU & Coastal & cormorants and pelicans \\
\hline Suliformes & Phalacrocoracidae & Leucocarbo carunculatus & Rough-faced Shag & VU & Coastal & cormorants and pelicans \\
\hline Suliformes & Phalacrocoracidae & Leucocarbo chalconotus & Stewart Shag & Vu & Coastal & cormorants and pelicans \\
\hline Suliformes & Phalacrocoracidae & Leucocarbo colensoi & Auckland Shag & VU & Coastal & cormorants and pelicans \\
\hline Suliformes & Phalacrocoracidae & Leucocarbo magellanicus & Rock Shag & LC & Coastal & cormorants and pelicans \\
\hline Suliformes & Phalacrocoracidae & Leucocarbo onslowi & Chatham Shag & $C R$ & Coastal & cormorants and pelicans \\
\hline Suliformes & Phalacrocoracidae & Leucocarbo ranfurlyi & Bounty Shag & VU & Coastal & cormorants and pelicans \\
\hline Suliformes & Phalacrocoracidae & Leucocarbo verrucosus & Kerguelen Shag & LC & Coastal & cormorants and pelicans \\
\hline Suliformes & Phalacrocoracidae & Microcarbo coronatus & Crowned Cormorant & NT & Coastal & cormorants and pelicans \\
\hline Suliformes & Phalacrocoracidae & Microcarbo melanoleucos & Little Pied Cormorant & LC & Coastal & cormorants and pelicans \\
\hline Suliformes & Phalacrocoracidae & Nannopterum auritus & Double-crested Cormorant & LC & Coastal & cormorants and pelicans \\
\hline Suliformes & Phalacrocoracidae & Nannopterum brasilianus & Neotropical Cormorant & LC & Coastal & cormorants and pelicans \\
\hline
\end{tabular}




\begin{tabular}{|c|c|c|c|c|c|c|}
\hline Order & Family & Scientific name & Common name & $\begin{array}{l}2018 \text { IUCN Red } \\
\text { List Category }\end{array}$ & $\begin{array}{c}\text { Pelagic / } \\
\text { coastal }\end{array}$ & Group \\
\hline Suliformes & Phalacrocoracidae & Nannopterum harrisi & Flightless Cormorant & VU & Coastal & cormorants and pelicans \\
\hline Suliformes & Phalacrocoracidae & Phalacrocorax capensis & Cape Cormorant & EN & Coastal & cormorants and pelicans \\
\hline Suliformes & Phalacrocoracidae & Phalacrocorax capillatus & Japanese Cormorant & LC & Coastal & cormorants and pelicans \\
\hline Suliformes & Phalacrocoracidae & Phalacrocorax carbo & Great Cormorant & LC & Coastal & cormorants and pelicans \\
\hline Suliformes & Phalacrocoracidae & Phalacrocorax featherstoni & Pitt Shag & EN & Coastal & cormorants and pelicans \\
\hline Suliformes & Phalacrocoracidae & Phalacrocorax fuscescens & Black-faced Cormorant & LC & Coastal & cormorants and pelicans \\
\hline Suliformes & Phalacrocoracidae & Phalacrocorax fuscicollis & Indian Cormorant & LC & Coastal & cormorants and pelicans \\
\hline Suliformes & Phalacrocoracidae & Phalacrocorax neglectus & Bank Cormorant & EN & Coastal & cormorants and pelicans \\
\hline Suliformes & Phalacrocoracidae & Phalacrocorax nigrogularis & Socotra Cormorant & VU & Coastal & cormorants and pelicans \\
\hline Suliformes & Phalacrocoracidae & Phalacrocorax punctatus & Spotted Shag & LC & Coastal & cormorants and pelicans \\
\hline Suliformes & Phalacrocoracidae & Phalacrocorax varius & Great Pied Cormorant & LC & Coastal & cormorants and pelicans \\
\hline Suliformes & Phalacrocoracidae & Poikilocarbo gaimardi & Red-legged Cormorant & NT & Coastal & cormorants and pelicans \\
\hline Suliformes & Phalacrocoracidae & Urile pelagicus & Pelagic Cormorant & LC & Coastal & cormorants and pelicans \\
\hline Suliformes & Phalacrocoracidae & Urile penicillatus & Brandt's Cormorant & LC & Coastal & cormorants and pelicans \\
\hline Suliformes & Phalacrocoracidae & Urile urile & Red-faced Cormorant & LC & Coastal & cormorants and pelicans \\
\hline Suliformes & Fregatidae & Fregata andrewsi & Christmas Frigatebird & CR & Pelagic & frigatebirds and tropicbirds \\
\hline Suliformes & Fregatidae & Fregata aquila & Ascension Frigatebird & VU & Pelagic & frigatebirds and tropicbirds \\
\hline Suliformes & Fregatidae & Fregata ariel & Lesser Frigatebird & LC & Pelagic & frigatebirds and tropicbirds \\
\hline Suliformes & Fregatidae & Fregata magnificens & Magnificent Frigatebird & LC & Pelagic & frigatebirds and tropicbirds \\
\hline Suliformes & Fregatidae & Fregata minor & Great Frigatebird & LC & Pelagic & frigatebirds and tropicbirds \\
\hline Suliformes & Sulidae & Morus bassanus & Northern Gannet & LC & Pelagic & gannets and boobies \\
\hline Suliformes & Sulidae & Morus capensis & Cape Gannet & EN & Pelagic & gannets and boobies \\
\hline Suliformes & Sulidae & Morus serrator & Australasian Gannet & LC & Pelagic & gannets and boobies \\
\hline Suliformes & Sulidae & Papasula abbotti & Abbott's Booby & EN & Pelagic & gannets and boobies \\
\hline Suliformes & Sulidae & Sula dactylatra & Masked Booby & LC & Pelagic & gannets and boobies \\
\hline Suliformes & Sulidae & Sula granti & Nazca Booby & LC & Pelagic & gannets and boobies \\
\hline Suliformes & Sulidae & Sula leucogaster & Brown Booby & LC & Pelagic & gannets and boobies \\
\hline Suliformes & Sulidae & Sula nebouxii & Blue-footed Booby & LC & Pelagic & gannets and boobies \\
\hline
\end{tabular}




\begin{tabular}{|c|c|c|c|c|c|c|}
\hline Order & Family & Scientific name & Common name & $\begin{array}{c}2018 \text { IUCN Red } \\
\text { List Category }\end{array}$ & $\begin{array}{c}\begin{array}{c}\text { Pelagic / } \\
\text { coastal }\end{array} \\
\end{array}$ & Group \\
\hline Suliformes & Sulidae & Sula sula & Red-footed Booby & LC & Pelagic & gannets and boobies \\
\hline Suliformes & Sulidae & Sula variegata & Peruvian Booby & LC & Pelagic & gannets and boobies \\
\hline
\end{tabular}

\section{References}

926 BirdLife International, 2018. IUCN Red List for birds. URL http://www.birdlife.org (accessed 10.12.18).

927 Croxall, J.P., Butchart, S.H.M., Lascelles, B., Stattersfield, A.J., Sullivan, B., Symes, A., Taylor, P., 2012. Seabird conservation status, threats and priority 928 actions: a global assessment. Bird Conservation International 22, 1-34. https://doi.org/10.1017/S0959270912000020 
Table A2.1. List of threats considered in the study. Adapted from IUCN (2012) and Salafsky et al. (2008).

\begin{tabular}{|c|c|c|c|}
\hline Threat & IUCN Level 1 & Source & Description (adapted from Salafsky et al. 2008) \\
\hline Agriculture & Agriculture \& Aquaculture & Terrestrial & Threats from farming and ranching as a result of agricultural expansion and intensification, including silviculture \\
\hline Aquaculture & Agriculture \& Aquaculture & Marine & $\begin{array}{l}\text { Threats from farming as a result of aquaculture and mariculture expansion and intensification (e.g. marine \& freshwater } \\
\text { aquaculture) }\end{array}$ \\
\hline Bycatch & Biological Resource Use & Marine & $\begin{array}{l}\text { Threats from the unintentional effects of the consumptive use of "wild" biological resources resulting in direct mortality or loss } \\
\text { of reproductive output }\end{array}$ \\
\hline $\begin{array}{l}\text { Climate change \& } \\
\text { severe weather }\end{array}$ & $\begin{array}{l}\text { Climate Change \& Severe } \\
\text { weather }\end{array}$ & - & $\begin{array}{l}\text { Long-term climatic changes that may be linked to global warming and other severe climatic or weather events outside the } \\
\text { natural range of variation that could eliminate a vulnerable species or habitat }\end{array}$ \\
\hline Diseases & $\begin{array}{l}\text { Invasive \& Other } \\
\text { Problematic Species, Genes } \\
\text { \& Diseases }\end{array}$ & $\begin{array}{l}\text { Terrestrial } \\
\text { or marine }^{1}\end{array}$ & $\begin{array}{l}\text { Threats from non-native and native pathogens/microbes that have or are predicted to have harmful effects on biodiversity } \\
\text { following their introduction, spread and/or increase in abundance }\end{array}$ \\
\hline Disturbance & $\begin{array}{l}\text { Biological Resource Use, } \\
\text { Human Intrusions \& } \\
\text { Disturbance }\end{array}$ & $\begin{array}{l}\text { Terrestrial } \\
\text { or marine }^{1}\end{array}$ & $\begin{array}{l}\text { Threats from human activities that alter, destroy and disturb habitats and species associated with non-consumptive uses of } \\
\text { biological resources }\end{array}$ \\
\hline $\begin{array}{l}\text { Energy } \\
\text { production \& } \\
\text { mining }\end{array}$ & Energy Production \& Mining & $\begin{array}{l}\text { Terrestrial } \\
\text { or marine }^{1}\end{array}$ & Threats from production of nonbiological resources \\
\hline Geological events & Geological Events & Terrestrial & Threats from catastrophic geological events \\
\hline Hunting/trapping & Biological Resource Use & $\begin{array}{l}\text { Terrestrial } \\
\text { or marine }^{1}\end{array}$ & $\begin{array}{l}\text { Threats from consumptive use of "wild" biological resources including deliberate harvesting effects; also persecution or control } \\
\text { of specific species }\end{array}$ \\
\hline $\begin{array}{l}\text { Invasive alien } \\
\text { species }\end{array}$ & $\begin{array}{l}\text { Invasive \& Other } \\
\text { Problematic Species, Genes } \\
\text { \& Diseases }\end{array}$ & Terrestrial & $\begin{array}{l}\text { Threats from non-native plants or animals that have or are predicted to have harmful effects on biodiversity following their } \\
\text { introduction, spread and/or increase in abundance }\end{array}$ \\
\hline Light pollution & Pollution & $\begin{array}{l}\text { Terrestrial } \\
\text { or marine }^{1}\end{array}$ & Threats from excess energy (light) \\
\hline $\begin{array}{l}\text { Logging \& wood } \\
\text { harvesting }\end{array}$ & Biological Resource Use & Terrestrial & Threats from harvesting trees and other woody vegetation for timber, fibre, or fuel \\
\hline $\begin{array}{l}\text { Natural system } \\
\text { modifications }\end{array}$ & $\begin{array}{l}\text { Natural System } \\
\text { Modifications }\end{array}$ & Terrestrial & $\begin{array}{l}\text { Threats from actions that convert or degrade habitat in service of "managing" natural or seminatural systems, often to improve } \\
\text { human welfare }\end{array}$ \\
\hline
\end{tabular}




\begin{tabular}{|c|c|c|c|}
\hline Threat & IUCN Level 1 & Source & Description (adapted from Salafsky et al. 2008) \\
\hline Overfishing & Biological Resource Use & Marine & $\begin{array}{l}\text { Threats from unintentional effects of consumptive use of "wild" biological resources resulting in resource competition or } \\
\text { indirect impacts on the ecosystem }\end{array}$ \\
\hline Pollution & Pollution & $\begin{array}{l}\text { Terrestrial } \\
\text { or marine }^{1}\end{array}$ & Threats from introduction of exotic and/or excess materials or energy (except light) from point and nonpoint sources \\
\hline $\begin{array}{l}\text { Problematic } \\
\text { native species }\end{array}$ & $\begin{array}{l}\text { Invasive \& Other } \\
\text { Problematic Species, Genes } \\
\& \text { Diseases }\end{array}$ & Terrestrial & $\begin{array}{l}\text { Threats from native plants or animals that have or are predicted to have harmful effects on biodiversity following their spread } \\
\text { and/or increase in abundance }\end{array}$ \\
\hline $\begin{array}{l}\text { Residential \& } \\
\text { commercial } \\
\text { development }\end{array}$ & $\begin{array}{l}\text { Residential \& Commercial } \\
\text { Development }\end{array}$ & Terrestrial & Human settlements or other non-agricultural land uses with a substantial footprint \\
\hline $\begin{array}{l}\text { Transportation \& } \\
\text { service corridors }\end{array}$ & $\begin{array}{l}\text { Transportation \& Service } \\
\text { Corridors }\end{array}$ & $\begin{array}{l}\text { Terrestrial } \\
\text { or marine }^{1}\end{array}$ & Threats from long, narrow transport corridors and the vehicles that use them including associated wildlife mortality \\
\hline
\end{tabular}

${ }^{1}$ Classification into terrestrial or marine made case by case, based on the references consulted (e.g. terrestrial if occurring on land, marine if at sea)


935 Table A2.2. Correspondence between the threats considered in the analyses (see A2.1.) and the original IUCN Red List threats classification scheme (IUCN, 2012)

\begin{tabular}{|c|c|c|c|c|c|}
\hline Threat & IUCN Level 1 & IUCN Level 2 & IUCN Level 3 & Source & Notes \\
\hline & & $\begin{array}{l}\text { Annual \& Perennial Non-Timber } \\
\text { Crops }\end{array}$ & $\begin{array}{c}\text { Shifting Agriculture, Small-holder Farming, Agro-Industry } \\
\text { Farming, Scale Unknown/Unrecorded }\end{array}$ & Terrestrial & \\
\hline \multirow[t]{2}{*}{ Agriculture } & $\begin{array}{l}\text { Agriculture \& } \\
\text { Aquaculture }\end{array}$ & Wood \& Pulp Plantations & $\begin{array}{c}\text { Small-holder Plantations, Agro-Industry Plantations, Scale } \\
\text { Unknown/Unrecorded }\end{array}$ & Terrestrial & \\
\hline & & Livestock Farming \& Ranching & $\begin{array}{c}\text { Nomadic Grazing, Small-Holder Grazing, Ranching or Farming, } \\
\text { Agro-Industry Grazing, Ranching or Farming, Scale } \\
\text { Unknown/Unrecorded }\end{array}$ & Terrestrial & \\
\hline Aquaculture & $\begin{array}{l}\text { Agriculture \& } \\
\text { Aquaculture }\end{array}$ & Marine \& Freshwater Aquaculture & $\begin{array}{c}\text { Subsistence/Artisanal Aquaculture, Industrial Aquaculture, Scale } \\
\text { Unknown/Unrecorded }\end{array}$ & Marine & \\
\hline Bycatch & Biological Resource Use & $\begin{array}{l}\text { Fishing \& Harvesting Aquatic } \\
\text { Resources }\end{array}$ & $\begin{array}{l}\text { Unintentional effects: subsistence/small scale (species being } \\
\text { assessed is not the target) [harvest], Unintentional effects: large } \\
\text { scale (species being assessed is not the target) [harvest] }\end{array}$ & Marine & $\begin{array}{l}\text { stress="species } \\
\text { mortality" }\end{array}$ \\
\hline \multirow{5}{*}{$\begin{array}{l}\text { Climate change \& } \\
\text { severe weather }\end{array}$} & & Droughts & & & \\
\hline & Climate Change \& Severe & Habitat Shifting \& Alteration & [No level 3 threats under Climate Change \& Severe Weather] & & \\
\hline & Weather & Other Impacts & & & \\
\hline & & Storms \& Flooding & & & \\
\hline & & Temperature Extremes & & & \\
\hline \multirow{5}{*}{ Diseases } & & $\begin{array}{l}\text { Invasive non-native/alien } \\
\text { species/diseases }\end{array}$ & Unspecified Species, Named Species & Terrestrial & $\begin{array}{c}\text { species=any } \\
\text { kind of disease }\end{array}$ \\
\hline & Invasive \& Other & Problematic native species/diseases & Unspecified Species, Named Species & Terrestrial & $\begin{array}{l}\text { species=any } \\
\text { kind of disease }\end{array}$ \\
\hline & $\begin{array}{l}\text { Problematic Species, } \\
\text { Genes \& Diseases }\end{array}$ & $\begin{array}{l}\text { Problematic species/disease of } \\
\text { unknown origin }\end{array}$ & Unspecified Species, Named Species & $\begin{array}{l}\text { Terrestrial, } \\
\text { marine (algal } \\
\text { blooms) }\end{array}$ & $\begin{array}{c}\text { species=any } \\
\text { kind of disease }\end{array}$ \\
\hline & & Viral/prion-induced diseases & Named "Species" (Disease), Unspecified "Species" (Disease) & Terrestrial & \\
\hline & & Diseases of unknown cause & & Terrestrial & \\
\hline \multirow[t]{2}{*}{ Disturbance } & Biological Resource Use & $\begin{array}{c}\text { Fishing \& Harvesting Aquatic } \\
\text { Resources }\end{array}$ & $\begin{array}{l}\text { Unintentional effects: subsistence/small scale (species being } \\
\text { assessed is not the target) [harvest], Unintentional effects: large } \\
\text { scale (species being assessed is not the target) [harvest] }\end{array}$ & Marine & \\
\hline & & Recreational Activities & & Terrestrial & \\
\hline
\end{tabular}




\begin{tabular}{|c|c|c|c|c|c|}
\hline Threat & IUCN Level 1 & IUCN Level 2 & IUCN Level 3 & Source & Notes \\
\hline & $\begin{array}{l}\text { Human intrusions \& } \\
\text { disturbance }\end{array}$ & Work \& Other Activities & & Terrestrial & \\
\hline \multirow{3}{*}{$\begin{array}{l}\text { Energy production } \\
\& \text { mining }\end{array}$} & \multirow{3}{*}{$\begin{array}{l}\text { Energy production \& } \\
\text { mining }\end{array}$} & Mining \& Quarrying & & Marine & \\
\hline & & Oil \& Gas Drilling & & Marine & \\
\hline & & Renewable Energy & & Marine & \\
\hline \multirow{2}{*}{ Geological events } & \multirow{2}{*}{ Geological events } & Avalanches/Landslides & & Terrestrial & \\
\hline & & Volcanoes & & Terrestrial & \\
\hline \multirow[b]{2}{*}{ Hunting/trapping } & \multirow[b]{2}{*}{ Biological Resource Use } & $\begin{array}{l}\text { Fishing \& Harvesting Aquatic } \\
\text { Resources }\end{array}$ & Persecution/Control & Marine & \\
\hline & & $\begin{array}{l}\text { Hunting \& Collecting Terrestrial } \\
\text { Animals }\end{array}$ & $\begin{array}{l}\text { Intentional use (species being assessed is the target), } \\
\text { Persecution/Control, Unintentional effects (species being } \\
\text { assessed is not the target) }\end{array}$ & $\begin{array}{l}\text { Terrestrial, } \\
\text { marine }^{1}\end{array}$ & \\
\hline $\begin{array}{l}\text { Invasive alien } \\
\text { species }\end{array}$ & $\begin{array}{l}\text { Invasive \& Other } \\
\text { Problematic Species, } \\
\text { Genes \& Diseases } \\
\end{array}$ & $\begin{array}{l}\text { Invasive Non-Native/Alien } \\
\text { Species/Diseases }\end{array}$ & Unspecified Species, Named species & Terrestrial & $\begin{array}{l}\text { species=any } \\
\text { non-disease }\end{array}$ \\
\hline Light pollution & Pollution & Excess Energy & Light Pollution & $\begin{array}{c}\text { Terrestrial, } \\
\text { marine }^{1}\end{array}$ & \\
\hline \multirow[b]{2}{*}{$\begin{array}{l}\text { Logging \& wood } \\
\text { harvesting }\end{array}$} & \multirow[b]{2}{*}{ Biological Resource Use } & Gathering Terrestrial Plants & Unintentional effects (species being assessed is not the target) & Terrestrial & \\
\hline & & Logging \& Wood Harvesting & $\begin{array}{l}\text { Unintentional effects: subsistence/small scale (species being } \\
\text { assessed is not the target) [harvest], Unintentional effects: large } \\
\text { scale (species being assessed is not the target) [harvest] }\end{array}$ & Terrestrial & \\
\hline \multirow[t]{2}{*}{$\begin{array}{l}\text { Natural system } \\
\text { modifications }\end{array}$} & \multirow[t]{2}{*}{$\begin{array}{l}\text { Natural System } \\
\text { Modifications }\end{array}$} & Dams \& Water Management/Use & $\begin{array}{l}\text { Abstraction of Surface Water (agricultural use), Abstraction of } \\
\text { Surface Water (domestic use), Abstraction of Surface Water } \\
\text { (unknown use), Dams (size unknown), Large Dams }\end{array}$ & Terrestrial & \\
\hline & & Fire \& Fire Suppression & $\begin{array}{c}\text { Increase in Fire Frequency/Intensity, Trend } \\
\text { Unknown/Unrecorded }\end{array}$ & Terrestrial & \\
\hline \multirow[t]{2}{*}{ Overfishing } & Biological Resource Use & $\begin{array}{l}\text { Fishing \& Harvesting Aquatic } \\
\text { Resources }\end{array}$ & $\begin{array}{l}\text { Unintentional effects: subsistence/small scale (species being } \\
\text { assessed is not the target) [harvest], Unintentional effects: large } \\
\text { scale (species being assessed is not the target) [harvest] }\end{array}$ & Marine & $\begin{array}{l}\text { stress="indirect } \\
\text { ecosystem } \\
\text { effects" or } \\
\text { "competition" }\end{array}$ \\
\hline & \multirow{3}{*}{ Pollution } & Agricultural \& Forestry Effluents & Herbicides and Pesticides, Nutrient Loads & Terrestrial & \\
\hline \multirow[t]{2}{*}{ Pollution } & & Domestic \& Urban Waste Water & Type Unknown/Unrecorded & Terrestrial & \\
\hline & & Garbage \& Solid Waste & & Terrestrial & \\
\hline
\end{tabular}




\begin{tabular}{|c|c|c|c|c|c|}
\hline Threat & IUCN Level 1 & IUCN Level 2 & IUCN Level 3 & Source & Notes \\
\hline & & Industrial \& Military Effluents & Oil Spills, Seepage from Mining, Type Unknown/Unrecorded & $\begin{array}{c}\text { Terrestrial, } \\
\text { marine (oil } \\
\text { spills) } \\
\end{array}$ & \\
\hline $\begin{array}{l}\text { Problematic native } \\
\text { species }\end{array}$ & $\begin{array}{l}\text { Invasive \& Other } \\
\text { Problematic Species, } \\
\text { Genes \& Diseases }\end{array}$ & Problematic Native Species/Diseases & Unspecified Species, Named Species & Terrestrial & \\
\hline \multirow{3}{*}{$\begin{array}{l}\text { Residential \& } \\
\text { commercial } \\
\text { development }\end{array}$} & \multirow{3}{*}{$\begin{array}{l}\text { Residential \& } \\
\text { Commercial } \\
\text { Development }\end{array}$} & Commercial \& Industrial Areas & & Terrestrial & \\
\hline & & Housing \& Urban Areas & & Terrestrial & \\
\hline & & Tourism \& Recreation Areas & & Terrestrial & \\
\hline \multirow{3}{*}{$\begin{array}{l}\text { Transportation \& } \\
\text { service corridors }\end{array}$} & \multirow{3}{*}{$\begin{array}{c}\text { Transportation \& Service } \\
\text { Corridors }\end{array}$} & Roads \& Railroads & & Terrestrial & \\
\hline & & Shipping Lanes & & Marine & \\
\hline & & Utility \& Service Lines & & Terrestrial & \\
\hline
\end{tabular}

$937{ }^{1}$ Classification of terrestrial or marine made case by case, based on the references consulted (e.g. terrestrial if occurring at the colony, marine if at-sea)

\section{References}

940 IUCN, 2012. Threats Classification Scheme (Version 3.2) [WWW Document]. URL http://www.iucnredlist.org/technical-documents/classification-

941 schemes/threats-classification-scheme. (accessed 10.9.18).

942 Salafsky, N., Salzer, D., Stattersfield, A.J., Hilton-Taylor, C., Neugarten, R., Butchart, S.H.M., Collen, B., Cox, N., Master, L.L., O'connor, S., Wilkie, D., 2008. A

943 Standard Lexicon for Biodiversity Conservation: Unified Classifications of Threats and Actions. Conservation Biology 22, $897-911$.

944 https://doi.org/10.1111/j.1523-1739.2008.00937.x 


\section{Appendix 3: Supporting figures}

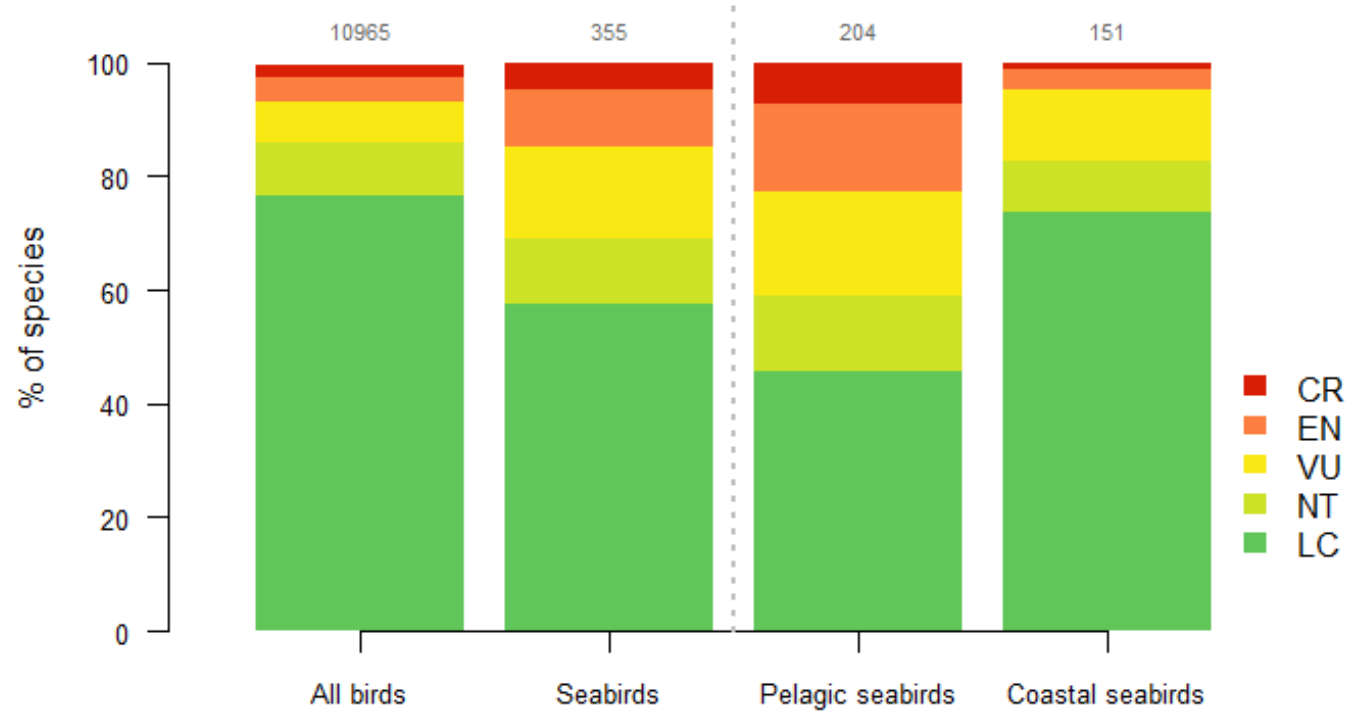

Figure A1: IUCN Red List status of all extant bird species, all seabirds, and pelagic and coastal seabird species (based on BirdLife International, 2018). Values atop bars indicate the number of species (species classified as "Data Deficient" (56, including 4 seabird species (all pelagic) are not shown). CR $=$ Critically Endangered; EN $=$ Endangered; VU = Vulnerable; NT = Near Threatened; $\mathrm{LC}=$ Least Concern. 


\section{Globally Threatened Species}

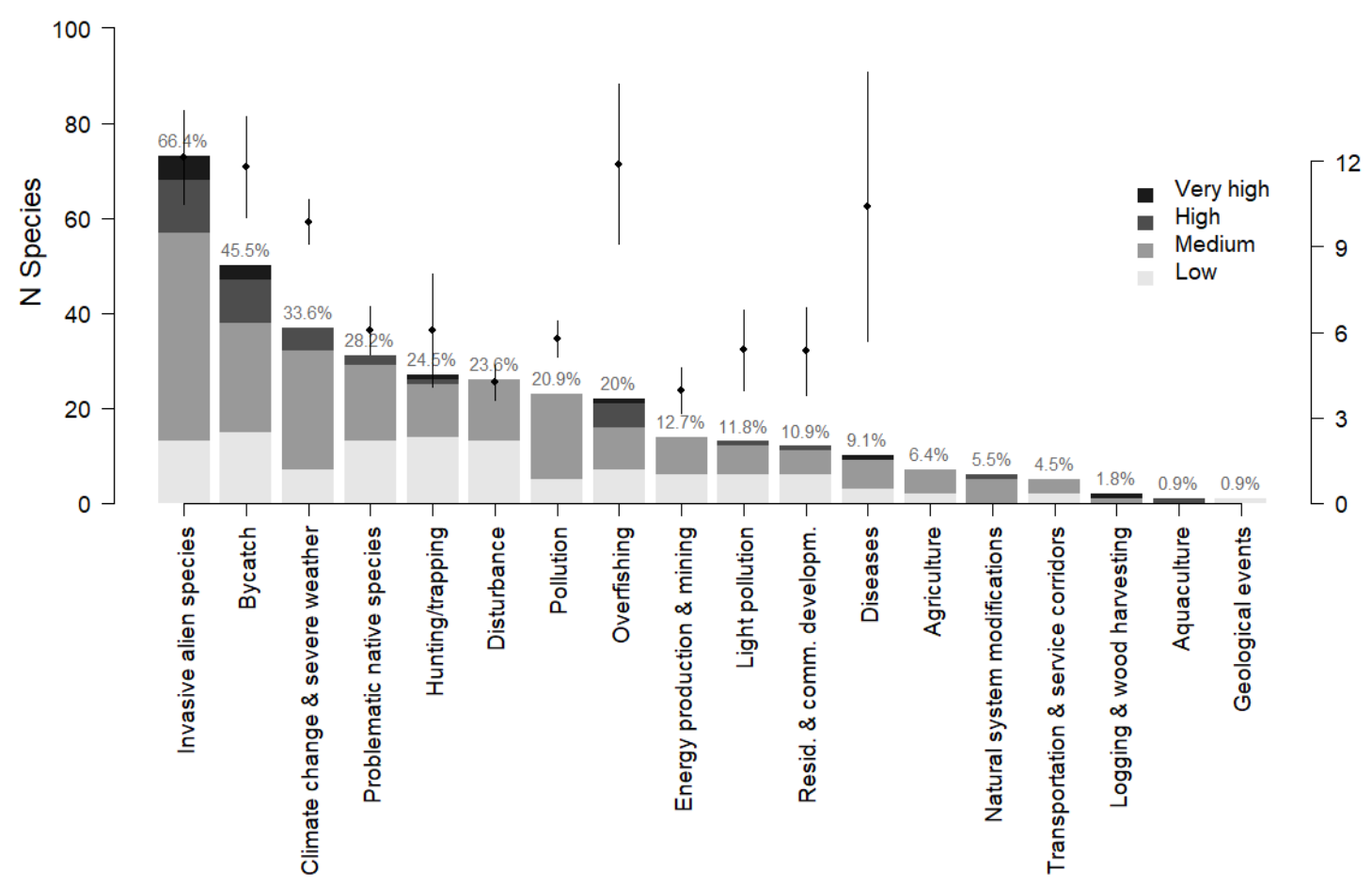

Figure A2: Ongoing threats to globally threatened seabird species (Critically Endangered, Endangered or Vulnerable). Left y axis: total number of species affected; Right y axis: average impact \pm SE. Values atop bars indicate the percentage of species affected $(n=110)$. 


\section{NT and declining LC}

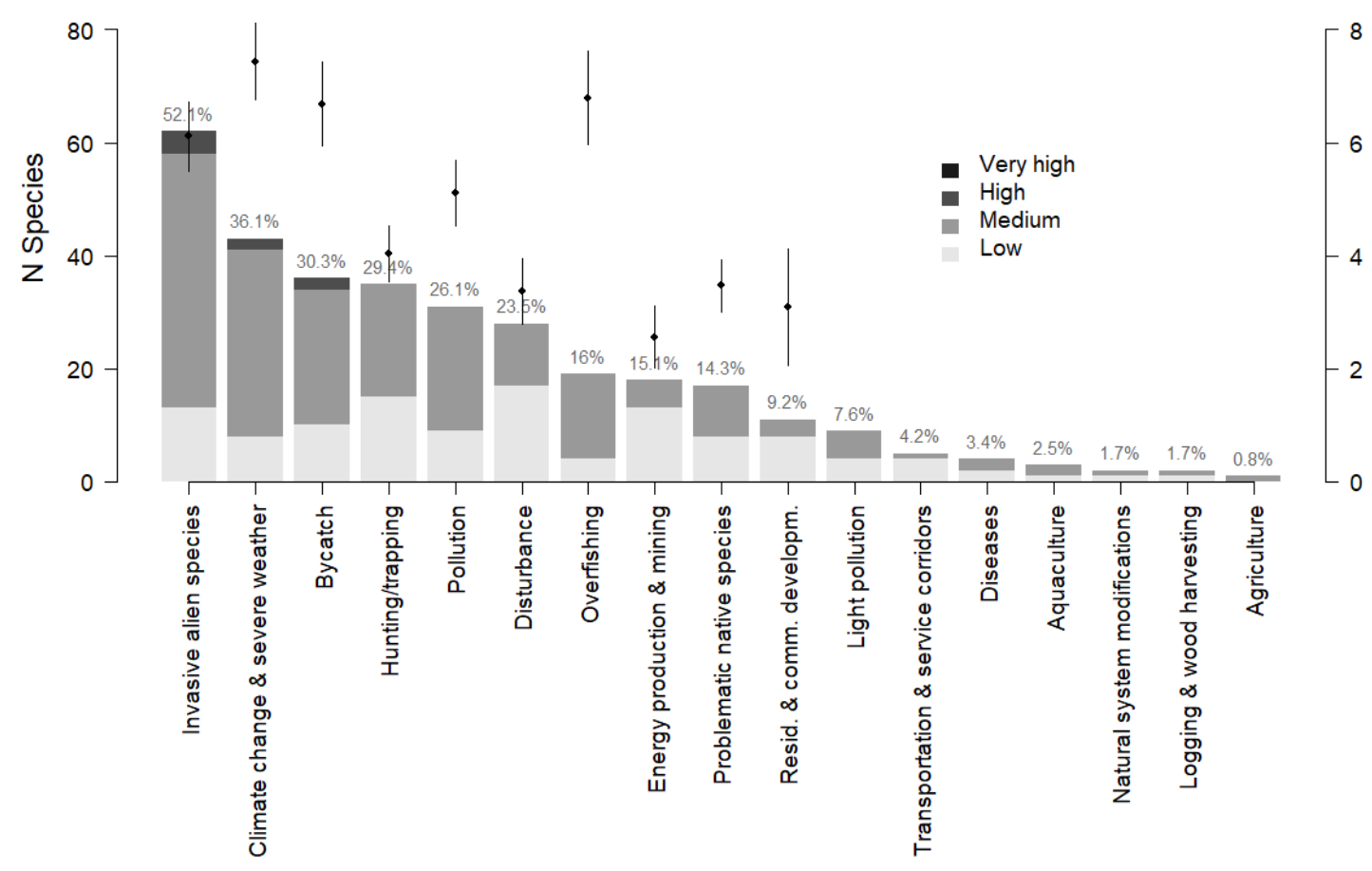

Figure A3: Ongoing threats to Near Threatened (NT) and declining Least Concern (LC) seabird species. Left y axis: total number of species affected; Right y axis: average impact \pm SE. Values atop bars indicate the percentage of species affected $(n=119)$. 


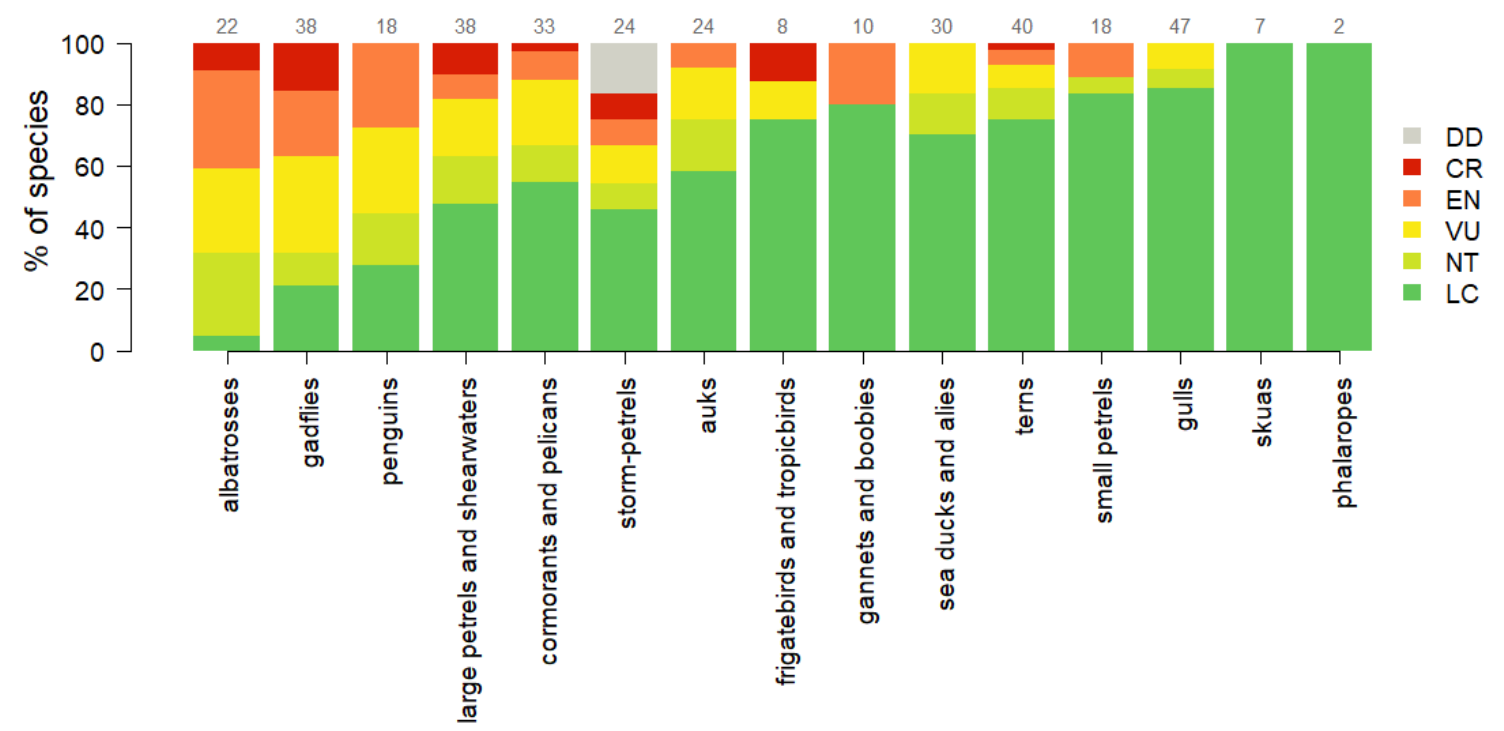

Figure A4: IUCN Red List status for each group of seabird species. Values atop bars indicate the number of species per group. $\mathrm{DD}=$ Data Deficient; $\mathrm{CR}=$ Critically Endangered; EN = Endangered; VU $=$ Vulnerable; NT $=$ Near Threatened; LC $=$ Least Concern . 


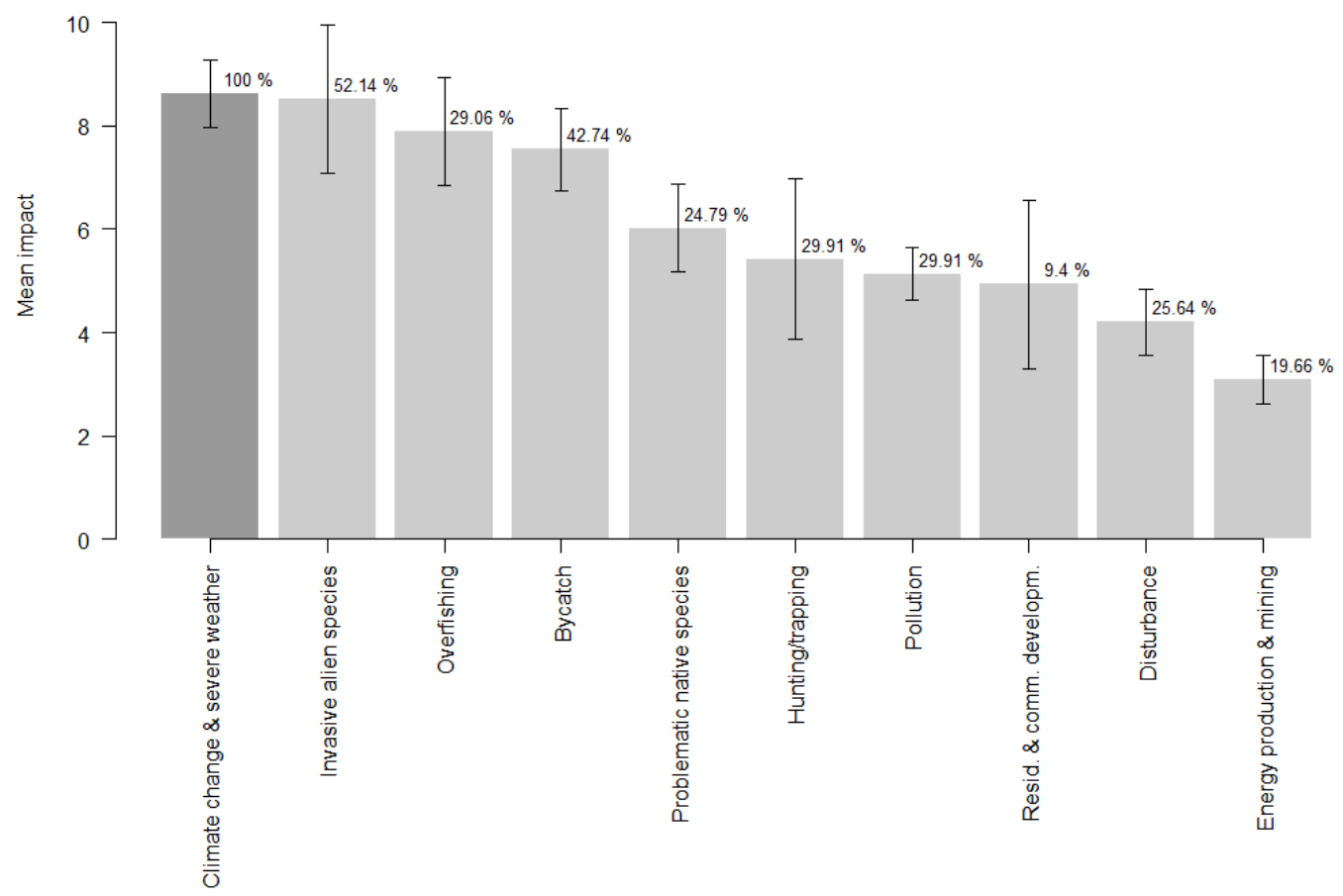

Figure A5: Mean impact ( $\pm \mathrm{EP}$ ) of threats co-occurring with climate change/severe weather $(\%$ indicate the percentage of species affected both by climate change/severe weather and each threat; only threats affecting more than 10 species are indicated) 


\section{References}

BirdLife International, 2018. IUCN Red List for birds [WWW Document]. URL http://www.birdlife.org (accessed 10.12.18). 